Andrews University

Digital Commons @ Andrews University

1996

\title{
A Plan for Strengthening Expository Preaching by Korean Seventh- day Adventist Pastors
}

Chongo Yang

Andrews University

Follow this and additional works at: https://digitalcommons.andrews.edu/dmin

Part of the Practical Theology Commons

\section{Recommended Citation}

Yang, Chongo, "A Plan for Strengthening Expository Preaching by Korean Seventh-day Adventist Pastors" (1996). Professional Dissertations DMin. 615.

https://digitalcommons.andrews.edu/dmin/615

This Project Report is brought to you for free and open access by the Graduate Research at Digital Commons @ Andrews University. It has been accepted for inclusion in Professional Dissertations DMin by an authorized administrator of Digital Commons @ Andrews University. For more information, please contact repository@andrews.edu. 
ABSTRACT

A PLAN FOR STRENGTHENING EXPOSITORY PREACHING BY KOREAN SEVENTH-DAY ADVENTIST PASTORS

by

Chongho Yang

Chair: Robert Johnston 


\section{ABSTRACT OF GRADUATE STUDENT RESEARCH \\ Dissertation}

Andrews University

Seventh-day Adventist Theological Seminary

\section{Title: A PLAN FOR STRENGTHENING EXPOSITORY PREACHING BY KOREAN SEVENTH-DAY ADVENTIST PASTORS}

Name of researcher: Chongho Yang

Name and degree nf sert Johnston, Ph.D.

\section{ANDREWS UNIVERSITY JAMES WHITE LIBRARY}

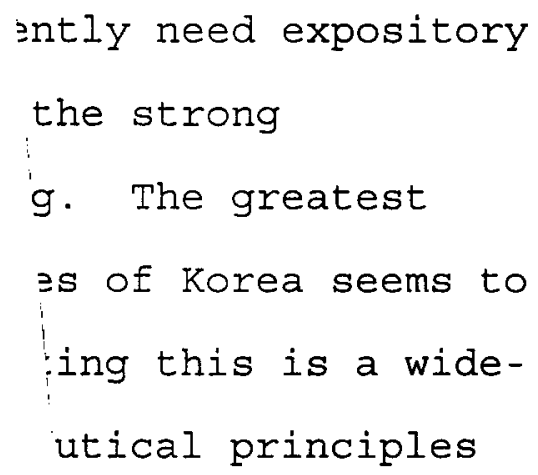

COVER: A PLAN FOR STRENGTHENING EXPOSITORY PREACHING BY KOREAN SEVENTH-DAY ADVENTIST PASTORS

A Dissertation for the degree of D.Min. Andrews University Chongho Yang 1996 
criteria were obtained from the review of biblical and current literature.

\section{Results}

It was found that of the fourteen sermons twelve sermons were not expository. Thus, it turns out that the solid understanding of how to make an expository sermon is greatly needed.

Conclusions

It is imperative that pastors and lay leaders receive adequate training in a continuing education program for expository preaching. Furthermore, the theology students of Sahmyook University, the future Adventist preachers of Korea, should learn how to research and construct a good expository sermon.

Therefore, a model for a course in expository preaching is presented in this dissertation. 
Andrews University

Seventh-day Adventist Theological Seminary

A PLAN FOR STRENGTHENING EXPOSITORY PREACHING

BY KOREAN SEVENTH-DAY ADVENTIST PASTORS

A Dissertation

Presented in Partial Fulfillment

of the Requirements for the Degree

Doctor of Ministry

by

Chongho Yang

December 1996 


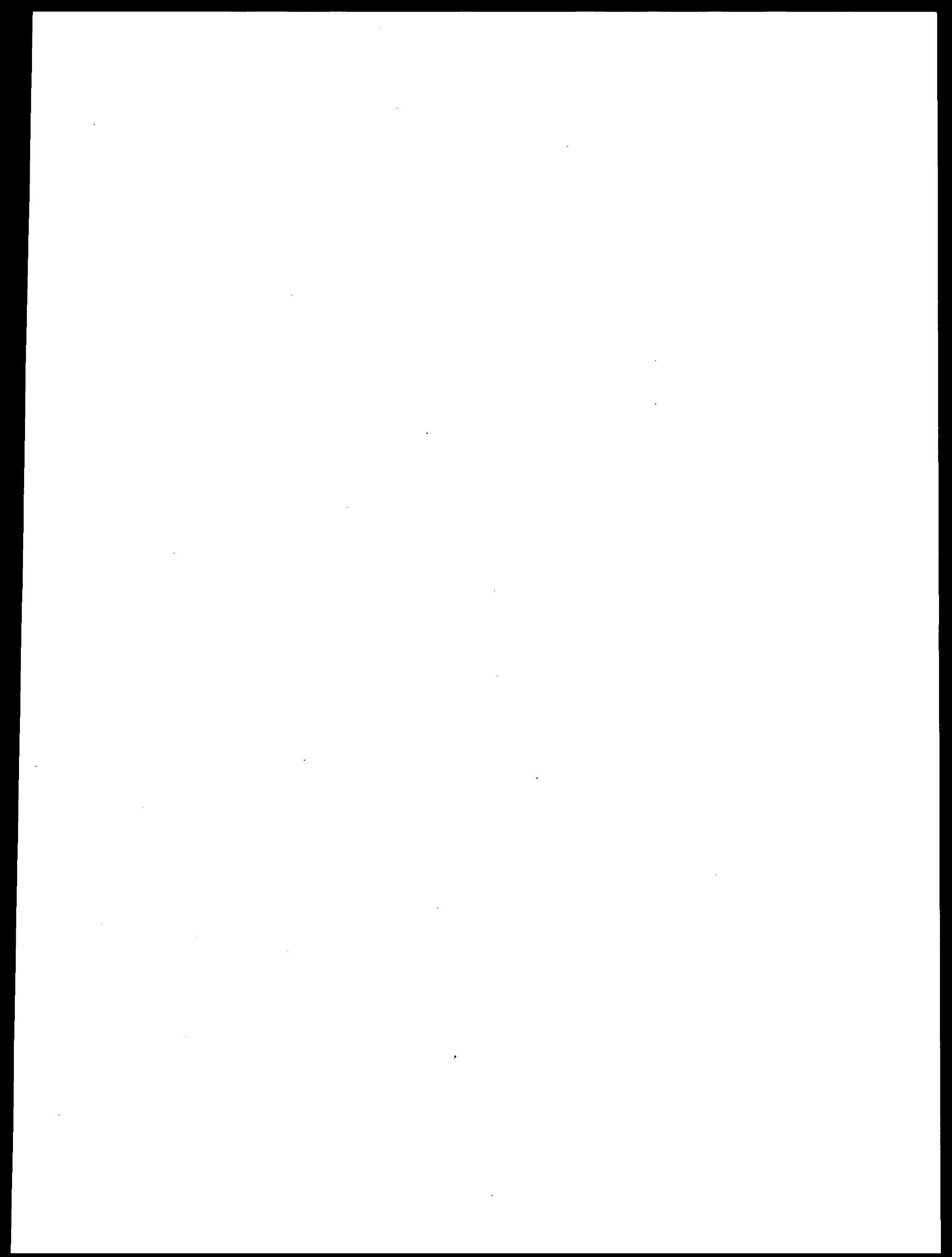


A PLAN FOR STRENGTHENING EXPOSITORY PREACHING

BY KOREAN SEVENTH-DAY ADVENTIST PASTORS

\section{A dissertation}

presented in partial fulfillment of the requirements for the degree

Doctor of Ministry

by

Chongho Yang

APPROVAL BY THE COMMITTEE:

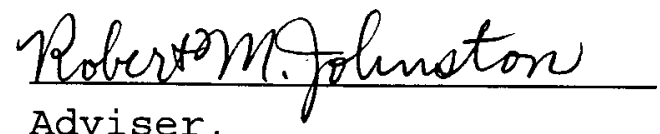
Adviser,

Robert Johnston

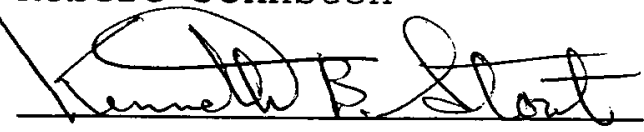

Kenneth stout

Brue L, Raver

Bruce Bauer

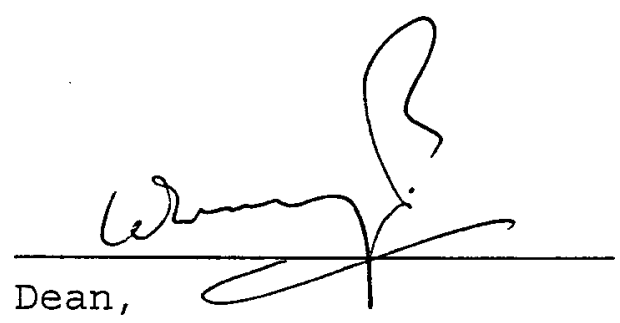

SDA Theological Seminary

ological Seminary

Decenbel 13,1956

Date approved 
To my beloved wife Namsoo, who has worked as hard as I have that this work could be done sucessfully. After God's help no other has identified so much with this research as she. May the Lord continue bestowing His blessings upon her. 
TABLE OF CONTENTS

ACKNOWLEDGMENTS . . . . . . . . . . . . . . . . . . vii

Chapter

I. INTRODUCTION . . . . . . . . . . . . . . . . . 1

Statement of the Problem . . . . . . . . 2

Purpose of the Study . . . . . . . . . . . . 3

Justification for the Dissertation . . . . . 3

Methodology of the Study . . . . . . . . 4

Limitation of the Study . . . . . . . . . 5

II. THE IMPORTANCE OF PREACHING . . . . . . . . . . . . 6

The Importance of Preaching . . . . . . . . . 6

Growing Worldliness of Church Members . . . 6

The Low Priority Attributed to

Preaching by Pastors . . . . . . . . . . 8

The Misunderstanding of the Writings of
Ellen G. White Regarding Preaching . . . 9

Jesus' Preaching . . . . . . . . . . . . . 14

The Example of the Primitive Church . . . . 15

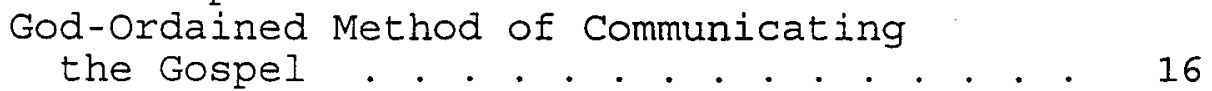

Preaching Is Revelation . . . . . . . . . 18

Proclaiming the Gospel Truth . . . . . . . 19

The Impact of Preaching on the History

of the Church . . . . . . . . . . . . 20

The Most Important Task Ever Assigned

to Man... . . . . . . . . . . . . . . 21

The Place of the Bible in Preaching. . . . . 23

God's Word and Human Needs . . . . . . . 26

III. THE NATURE OF EXPOSITORY PREACHING . . . . . . . 28

Expository Preaching in selected

Contemporary Literature... . . . . . . 28

Definitions of Expository Preaching . . . 28

More Than Two Verses . . . . . . . . . . 29

Connected Series of a Book . . . . . . 31

Major and Minor Divisions . . . . . . . 32

Verse By Verse . . . . . . . . . . 33

Explanation Type . . . . . . . . . . 34 
Homiletical Freedom . . . . . . . . . 38

Criteria for an Expository Sermon . . . . . 39

Hermeneutical Principles......... . 40

Homiletical Rules :. . . . . . . . . . . 45

Summary of Expository Criteria . . . . . . 47

IV. THE NEED FOR EXPOSITORY PREACHING . . . . . . . 49

The Three Factors of Expository Preaching . . 49

The Advantages of Expository Preaching . . . 52

It Returns Preaching to Its Expository Roots 57

Expository Preaching in the old Testament. 57

Expository Preaching in the New Testament. 59

Jesus' Preaching . . . . . . . . . . 59

Peter's Preaching. . . . . . . . . . 62

Paul's Preaching . . . . . . . . . 66

V. THE DEVELOPMENT OF THE ADVENTIST CHURCH AMONG

OTHER RELIGIONS IN KOREA . . . . . . . . . . . . 69

VI. AN ANALYTICAL STUDY OF ADVENTIST PREACHING

IN THE REPUBLIC OF KOREA . . . . . . . . . . . . 73

Classifying and Analyzing Sermons: A Matrix . 73

Synopsis and Analysis of Fourteen Sermons

in Korea

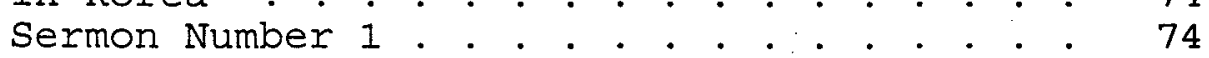

Sermon Number 2 . . . . . . . . . . . . 79

Sermon Number 3 . . . . . . . . . . . 82

Sermon Number 4 . . . . . . . . . . . . . 89

Sermon Number 5. . . . . . . . . . . . 92

Sermon Number 6 . . . . . . . . . . . . . 99

Sermon Number 7 . . . . . . . . . . . . . 104

Sermon Number 8. . . . . . . . . . . . 109

Sermon Number 9. . . . . . . . . . . . . . 114

Sermon Number 10 . . . . . . . . . . . . 118

Sermon Number 11 . . . . . . . . . . . . . 124

Sermon Number 12 . . . . . . . . . . . . 127

Sermon Number 13 . . . . . . . . . . . . . 129

Sermon Number 14 . . . . . . . . . . . . . 134

Observations/Conclusions . . . . . . . . 138

Observations . . . . . . . . . . . . . . 138

Conclusions . . . . . . . . . . . . . . . 140

APPENDIX . . . . . . . . . . . . . . . . . . . . . 142

A. A Model Outline for A Course in Expository

Preaching... . . . . . . . . . . . 142

Lesson One: Establishing A Text . . . . 143

Lesson Two: Exegesis . . . . . . . . 145

Lesson Three: Explanation . . . . . . 149

Lesson Four: Christ-Centered Preaching . 151 
Lesson Five: Application . . . . . . . 153

Lesson Six: Preacher's RSVP . . . . . . . 155

SELECTED BIBLIOGRAPHY . . . . . . . . . . . . . 158 


\section{ACKNOWLEDGMENTS}

I wish to express appreciation to the following individuals:

Drs. Robert Johnston, Kenneth Stout, and Bruce Bauer for the many hours of evaluation and encouragement which led to the finishing of this study.

Drs. Werner and Nancy Vyhmeister, Benjamin Schoun, Douglas Kilcher, Antonio Bueno, James North, Raoul Dederen, Norman Miles, and Dr. and Mrs. C. Raymond Holmes for their kindness and encouragement.

\section{All the pastors of the Korean Union Conference} who supported this study by sharing their sermon tapes.

Dr. Leona Running and Mrs. Bonnie Proctor for their repeated revisions of the paper until it was ready.

My coworkers and friends who have supported me in an unforgettable way.

My son Justin for his understanding and prayer as I strived to finish this task.

Finally, to the Father who grants strength, wisdom, and time, Jesus my Redeemer, and the Eternal Counselor be the glory and the honor for enabling me to do this task. 
CHAPTER I

INTRODUCTION

As Andrew Blackwood observed in his day, preaching is "the finest of the fine arts," because its aim is to "move the will of the hearer Godwards."1 A few years later Merrill Unger forcefully stated: "One of the most fundamental needs of the human race is deliverance from the penalty and power of sin."2 And then Herbert Farmer wrote, in reference to the impact of preaching, "In the proclamation man is personaliy addressed by the eternal Word of God. He is offered deliverance. God speaks: man must respond. The demand for decision is inescapable." 3 Therefore, Robert Mounce said: "To proclaim the message of divine deliverance is the most solemn responsibility ever entrusted to mortal man."4

${ }^{1}$ Andrew W. Blackwood, The Fine Art of Preaching (New York: Macmillan, 1952), 22. In this dissertation "preaching" will be used with a very broad meaning. It will include situations that could also be called teaching.

${ }^{2}$ Merrill F. Unger, Principles of Expository Preaching (Grand Rapids, MI: Zondervan, 1955), 29.

${ }^{3}$ Herbert H. Farmer, The secret of the Word (New York: Charles Scribner's Sons, 1942), 155.

${ }^{4}$ Robert $H$. Mounce, The Essential Nature of New Testament Preaching (Grand Rapids, MI: Eerdmans, 1960), 158. 
Despite a general consensus among preachers that preaching is important, the pulpit has today become weak, and the church has lost its vitality. One of the reasons for this may be the type of preaching that is commonly employed today. As Unger pointed out, "the popular 'springboard sermon' which employs a passage from the Bible as a starting point for a discourse on morality or sociology, or some other worthy but not strictly Biblical subject, "1 prevails.

His observation made in the mid-fifties still applies today. There seems to be a dearth of in-depth biblical preaching. Such in-depth preaching, sometimes called "expository preaching," could revive the church by providing a stronger spiritual diet for believers. Expository preaching tends to draw sermons from larger portions of the Bible and bases its structure and content directly on God's Word.

\section{Statement of the Problem}

Adventist churches in Korea urgently need expository preaching to act as a counterbalance to the strong traditional emphasis on topical preaching. The greatest problem of preaching in Adventist churches of Korea seems to be a lack of biblical content. Complicating this is a wide-

\footnotetext{
${ }^{1}$ Unger, 33 .
} 
spread failure to correctly apply hermeneutical principles to biblical exposition.

\section{Purpose of the Study}

The task of this dissertation is threefold: (1) to more sharply define and better comprehend expository preaching, (2) to analyze selected Seventh-day Adventist Korean preachers' sermons in light of the criteria established for authentic expository preaching, ${ }^{1}$ and (3) to design a model for a course in expository preaching which can be applied to the Korean Adventist context.

\section{Justification for the Dissertation}

Many Korean Adventists have strayed into false doctrines partly because they have not been sufficiently nurtured by the word of God. I believe that expository preaching has the potential to reverse this trend by stressing greater in-depth instruction in the teachings of Scripture.

Based on my personal observation as a pastor, a considerable number of Korean Adventists in the church do not have the assurance of salvation. I believe that one of the reasons for this is that Christ-centered, expository preaching is seldom heard. There has been a tendency for Korean ministers to focus on ethical instructions, pietistic

\footnotetext{
${ }^{1}$ These criteria will be determined through a survey of relevant literature, which will constitute part of the dissertation.
} 
exhortations, or Christian moral education-often based on personal opinion-instead of Christ and His gospel of grace as taught in scripture. The pulpit is the place where the pure Word of God and not the concepts or opinions of individuals are to be preached.

It is highly desirable that the theology students of Sahmyook University, the future preachers of Korea, should be instructed and trained in expository preaching because this method can help them fulfill their responsibility to preserve and correctly communicate biblically-based Adventist theology. The expository model to be developed in this dissertation can, it is hoped, be used to instruct these students.

\section{Methodology of the Study}

Most of the resources to be used in this project came from the James White Library at Andrews University in Berrien Springs, Michigan. Other material was acquired through interlibrary loan services from universities around North America and Korea.

A theological foundation is first laid regarding the importance of preaching, the place of the Bible in preaching, and God's Word and human needs.

Next, the nature of expository preaching is explored. For that a review of selected literature dealing with expository preaching is made in order to further define and establish criteria for expository preaching. 
Then, the need for expository preaching is discussed. This includes the advantages and biblical roots of expository preaching.

Two taped sermons presented by each of seven selected Seventh-day Adventist preachers in Korea were collected and analyzed in the light of the criteria established for authentic expository preaching. The pastors selected include: three pastors between the ages of twentyfive and forty-four, four pastors between the ages of fortyfive and sixty-four.

The preachers were not specifically requested to supply expository sermons. They were just requested to supply their favorite sermons.

This analysis gives some indication of the amount of expository preaching done by these pastors and the detailed procedure employed in the preparation of expository sermons. In view of the need discovered, a model for a course in expository preaching was designed for use by Korean pastors and theology students.

\section{Limitations of the study}

Two sermons by each of seven ministers were analyzed. Each of the ministers was drawn from seoul and its vicinity. The sermons were limited to those preached in the last five years. 
CHAPTER II

THE IMPORTANCE OF PREACHING

The purpose of this chapter is to lay a theological foundation regarding the importance of preaching, the place of the Bible in preaching, and preaching to meet ultimate human needs.

\section{The Importance of Preaching}

Preaching has been credited with helping to sustain the health and vitality of the church. Yet, preaching today is in crisis. There are many reasons for this. Some of them are the growing worldliness of church members, the low priority attributed to preaching by pastors, and the misunderstanding in Korea of Ellen G. White's counsel regarding preaching. In this section, the reasons are explored and a case is made for the continuing importance of preaching.

Growing Worldliness of Church Members The nineteenth century saw the heyday of preaching. However, the twentieth century experienced a new phenomenon in which society "has questioned most forms of authority, 
and seen the advent of television." ${ }^{1}$ In this era, preaching takes place in an overcommunicated society. Mass media bombard people with a great many messages each day. As Haddon Robinson aptly described, television and radio feature pitchmen who are "delivering a word from the sponsor with all the sincerity of an evangelist. Within that context the preacher may sound like another huckster who - . plays stage tricks with the doctrines of life and death."2 With penetrating insight, Robinson sees that "multimedia presentations, filmstrips, sharing sessions, blinking lights, and up-to-date music may be symptoms of either health or disease." ${ }^{3}$ Affected by this overwhelming inflow of worldly values and issues, people, including church members, are becoming worldly. They tend to deny the authoritative word of God. They choose relativism. They enjoy pseudo-paradise. Therefore, they do not like preaching which draws sharp distinctions between right and wrong. Preachers are affected by worldliness, too. They often lack the power of the Holy spirit. Their confidence in preaching's ability to make a serious impact is also diminished. Even as early as 1940, Jefferson Ray concluded.

\footnotetext{
${ }^{1}$ Neil Richardson, Preaching from Scripture (London: Epworth Press, 1983), 103.

${ }^{2}$ Haddon W. Robinson, Biblical Preaching (Grand Rapids, MI : Baker, 1980), 16.
}

${ }^{3}$ Ibid. 
that "except for the growing worldliness of its members, the pulpit is the church's weak spot."1

In more recent times, Donald Macleod sharply warned that both laypersons and ministers have lost confidence in the effect of preaching on the church. He quoted a doctoral dissertation on preaching at Princeton Theological Seminary by Gilbert Doan, Jr., a Lutheran minister:

American Protestants are losing their confidence in the sermon as an authentic mode of Christian communication, and in the preaching office as an essential mark of the Church. Laypersons are increasingly unwilling to testify that preaching means anything important to them. As a result, ministers feel more and more that their time is better invested elsewhere. The predictable result is preaching of a steadily declining quality, of which the laity have become less and less tolerant. ${ }^{2}$

The Low Priority Attributed to Preaching by Pastors

Why does preaching receive low grades in local churches? Kyle Haselden depicted the pastor who comes across as the congregation's "congenial, ever helpful, ever ready to help boy scout, as the darling of the old ladies and as sufficiently reserved with the young ones, as the father image for the young people and a companion to lonely

${ }^{1}$ Jefferson D. Ray, Expository Preaching (Grand Rapids, MI : Zondervan, 1940), 14 .

${ }^{2}$ Gilbert Doan, Jr., quoted in Donald Macleod, The Problem of Preaching (Philadelphia, PA: Fortress, 1987), 11. 
man." If it is true that the pastor is trying to do and to be so many things, it is not surprising that many preachers are investing less time in preparing sermons and, therefore, compromising their preaching quality. Robinson says, "If that pictures reality at all, while the preacher may be liked, he will certainly not be respected." 2 Also the weak pulpit, i.e., the generally weak quality of sermons, may be one of the reasons for the short tenure of many pastors in a church.

The Misunderstanding of the Writings of Ellen G. White Regarding Preaching

To some Adventist pastors, the misunderstanding of the writings of Ellen G. White, ${ }^{3}$ one of the founders of the Seventh-day Adventist Church, may be another factor in weakening the Adventist pulpit. She wrote: "Read the Scriptures carefully, and you will find that Christ spent the largest part of His ministry in restoring the suffering

\footnotetext{
${ }^{1}$ Kyle Haselden, The Urgency of Preaching (New York: Harper \& Row, 1963), 88-89.

${ }^{2}$ Robinson, 16 .

${ }^{3}$ Mrs. Ellen Gould (Harmon) White (1827-1915) was one of the founders of the Seventh-day Adventist Church. She was writer, lecturer, preacher, and counselor to the church. She is accepted as one who possessed the prophetic gift described in the Bible. During her lifetime she wrote over 5,000 articles and twenty-six books, including compilations from her 55,000 pages of manuscripts.
} 
and afflicted to health." ${ }^{1}$ Also, she observed: "During His ministry, Jesus devoted more time to healing the sick than to preaching." 2

Some Adventist ministers have been urged to follow the example of Jesus by devoting more time to giving Bible studies, visiting souls, taking care of the sick, and serving people than to preparing sermons and preaching. I heard an Adventist layperson go so far as to say, "Preaching is not a ministry in the light of the writings of Ellen $G$. White." Mrs. White, however, never wrote or even intimated this. It appears that some Adventist ministers have mixed feelings about the role and importance of preaching. They appreciate good sermons and want and ask for them. Many of them, however, do not regard preaching as the most important ministry. In part, this is due to a misunderstanding of the writings of Ellen G. White, as noted above. A pastor in Korea, for example, was persuaded by some leaders of the local and the union conference that he should devote more time to giving Bible studies and visiting people than to preaching. Their advice was based on what they understood to be the counsel of Ellen G. White. As a result, this pastor's preaching became a burden and he and his congregation both became disappointed in his sermons. He

${ }^{1}$ Ellen $G$. White, Medical Ministry (Mountain View, CA: Pacific Press, 1963), 240 .

${ }^{2}$ Ellen $\mathrm{G}$. White, The Ministry of Healing (Mountain View, CA: Pacific Press, 1942), 19. 
came to the brink of physical, mental, and spiritual burnout.

It is important for ministers to give Bible studies and visit people, including the sick. It is also important, however, to prepare sermons and preach to serve the people's spiritual needs. What Mrs. White meant by the statement noted above was that Jesus met people's physical and mental needs as One who desired their good so that He might open their minds and hearts and serve their spiritual needs. The Master tried to show people how healing the sick and performing other acts of mercy were opening wedges that made people receptive to the spiritual messages embodied in teaching and preaching. The story of the paralytic at Bethesda is a good example. Christ wanted to let people know that He was the one who delivered them from sin by delivering them from their sickness. Therefore Mrs. White, through these words quoted above, wanted to reveal one of the characteristics of Christ's work in which spiritual work was manifested by physical work. She wrote so, not to show the ratio of time which should be invested in serving people, but to show how Jesus worked to supply people's physical needs in order to create a receptivity to His spiritual message. Therefore, Ellen White's teachings about a minister's work must be kept in balance. 
She warned that "many do not look upon preaching as Christ's appointed means of instructing His people." ${ }^{1}$ She also said that preaching is "God's appointed means of saving souls." ${ }^{2}$

When a pastor is busy doing things which laypersons can do, he or she cannot be called an effective minister. Preaching and other duties will suffer. Mrs. White gave an illustration about this:

In some respects the pastor occupies a position similar to that of the foreman of a gang of laboring men. . . . The owner of a large mill once found his superintendent in a wheel-pit, making some simple repairs, while a half-dozen workmen in that line were standing by, idly looking on. The proprietor, after learning the facts, so as to be sure that no injustice was done, called the foreman to his office and handed him his discharge with full pay. In surprise the foreman asked for an explanation. It was given in these words: "I employed you to keep six men at work. I found the six idle, and you doing the work of but one. Your work could have been done just as well by any one of the six. I cannot afford to pay the wages of seven for you to teach the six how to be idle." 3

The foreman's primary job was to guide and support his workers so that they might work well. So it is with a pastor. A principal part of his work is to guide and support laypersons so that they may serve people well.

${ }^{1}$ Ellen G. White, Testimonies for the Church, 9 vols. (Mountain View, CA: Pacific Press, 1948), 5:298.

${ }^{2}$ Ibid., 300 .

${ }^{3}$ Ellen G. White, Gospel Workers (Washington, DC: Review and Herald, 1915), 197. 
Thus, the minister can be freed to carry out other duties such as preaching.

The experience of the N.T. Church teaches the importance of delegating authority to laypersons so that the Word could be taught and preached. When there was an issue on feeding and fulfilling people's physical needs, the apostles said, "It would not be right for us to neglect the ministry of the word of God in order to wait on tables" (Acts $6: 2$ ). ${ }^{1}$ They put their highest priority on preaching. Thus they had all the disciples choose the appropriate persons to do the food distribution ministry. They said, "We will turn this responsibility over to them and will give our attention to prayer and the ministry of the word" (Acts $6: 3-4)$

It is indispensable to understand the writings of Ellen white in their context. Right after the sentence, "During His ministry, Jesus devoted more time to healing the sick than to preaching," comes this phrase:

His miracles testified to the truth of His words, that He came not to destroy, but to save. . . . The Savior made each work of healing an occasion for implanting divine principles in the mind and soul. This was the purpose of His work. He imparted earthly blessings, that He might incline the hearts of men to receive the gospel of His grace (emphasis supplied). ${ }^{2}$

${ }^{1}$ Unless otherwise noted, biblical texts are quoted from the New International Version (NIV).

${ }^{2}$ White, The Ministry of Healing, 19-20. 
Her main purpose in these writings was not to show the appropriate allocation of time, but to make clear that Jesus' healing and acts of kindness prepared the way for Him to proclaim (i.e., to preach) the gospel. (See Luke 4:1619.) As Ellen White stated, Jesus did spend more time healing so that the people would be receptive to His preaching; He still spent much time in preaching and in preparing to preach; think of those long, quiet nights of prayer and study! Therefore the conclusion that contemporary preachers should spend little time in preaching is questionable.

Although there is a growing worldliness of people including church members, a tendency of pastors to put a low priority on preaching, and a misunderstanding of the writings of Ellen G. White by some Adventists, there is hope for the pulpit. Why? Because a strong case can be made for the importance of preaching. Notice, for example, Jesus' preaching pattern.

\section{Jesus' Example}

Jesus preached. He went throughout Galilee, preaching (Matt 4:23). He "traveled about from one town and village to another, proclaiming" (Luke 8:1). Preaching was one of the reasons why He came to this world. He said: "Let us go somewhere else-to the nearby villages-so I can preach there also. That is why I have come" (Mark 1:38, emphasis supplied). Jesus also stated His mission this way: 
"The Spirit of the Lord is on me, because he has anointed me to preach good news. He has sent me to proclaim.. ." (Luke $4: 18$ ).

He not only preached but also sent His disciples to preach. Notice these references: "When Jesus had called the Twelve together, . . he sent them out to preach" (Luke $9: 1,2)$; "So they set out and went from village to village, preaching" (Luke $9: 6$ ).

Jesus wants the gospel to be preached to all

nations. When He was resurrected, He prophesied that preaching would continue (Luke 24:47). He said to His disciples as His last words, "Go into all the world and preach" (Mark 16:15). Even though there were many methods open to Jesus, He deliberately selected the method of preaching.

The Example of the Primitive Church

After Jesus' ascension, "the disciples went out and preached everywhere" (Mark 16:20). Following their Savior's command, even when they were persecuted, they "preached the word wherever they went" (Acts 8:4). In Acts we are told, "Day after day, in the temple courts and from house to house, they never stopped . . proclaiming the good news that Jesus is the Christ" (Acts $5: 42$ ).

When Paul was chosen to be Christ's instrument, "at once he began to preach" (Acts 9:20). He was "so eager to preach the gospel" (Rom 1:15), "compelled to preach" (1 Cor 
9:16), that he "devoted himself exclusively to preaching" (Acts 18:5). In view of these records, the power and growth of the apostolic church must be attributed-to a significant degree-to preaching.

\section{God-Ordained Method of Communicating the Gospel}

The word preaching comes from the Latin word praedicare, and means proclaiming.' It is "the proclamation of a divine message" ${ }^{2}$ to men and women. In the view of P. T. Forsyth, "preaching is the most distinctive institution in Christianity." ${ }^{3}$ Charles Koller says that "preaching originated in the mind of God, and is His own distinctive medium for reaching the hearts of men with a message that is calculated to save the soul"4 (emphasis supplied).

About the state of this world, Faris Whitesell stated that "we live in a confused, worried, groping and lost world. It is looking for a way out. All human philosophies, panaceas and programs have failed. Chaos,

${ }^{1}$ Alexander James Grieve, "Preaching," The Encyclopedia Britannica, 13th ed. (1926), $22: 263$.

${ }^{2}$ Ibid.

${ }^{3}$ P. T. Forsyth, Positive Preaching and Modern Mind (London: Hodder and Stoughton, 1907), 3 .

${ }^{4}$ Charles W. Koller, Expository Preaching without Notes (Grand Rapids, MI: Baker, 1962), 13. 
tragedy and destruction impend." 1 He goes on to say that preaching is, therefore, "God's ordained way to meet the needs of such a world as this." 2 Andrew Blackwood reminds us that "God makes Himself known in three ways: supremely in Christ, largely through the Bible, and also through the preacher today. ${ }^{3}$

It is message and witness that constitute preaching. ${ }^{4}$ Therefore, preachers are witnesses and messengers. Another word that embodies the work of the preacher is "herald." Mounce reveals the importance of a herald by saying:

The herald was a figure of prominence and importance in the Hellenistic world. His employer was the king or the state; his duty was to make official proclamations; and because of his vital role in cultic sacrifice, he acquired a distinct religious significance. ${ }^{5}$

Likewise preachers are sent to proclaim. The Apostle Paul said, "How can they preach unless they are sent?" (Rom 10:15). No words could emphasize the importance of preaching as the divine call more than this verse. Preachers are sent by God. Therefore he wrote, "The elders

\footnotetext{
${ }^{1}$ Faris D. Whitesell, The Art of Biblical Preaching (Grand Rapids, MI: Zondervan, 1950), 16.

${ }^{2}$ Ibid.

${ }^{3}$ Andrew W. Blackwood, The Preparation of Sermons (New
} York: Abingdon-Cokesbury, 1948), 25.

${ }^{4}$ Phillips Brooks, Lectures on Preaching (London: H. R. Allenson, 1871), 14 .

${ }^{5}$ Mounce, 14 . 
who direct the affairs of the church well are worthy of double honor, especially those whose work is preaching" (1 $\operatorname{Tim} 5: 17)$.

\section{Preaching Is Revelation}

God speaks (Heb 1:1, 2). As John stott asks, "How could we ever dare to speak if God has not spoken?"1 One of the means by which God speaks is preaching. Therefore, Mounce suggests that "preaching . . . is revelation."2 Herbert Farmer observed of a sermon: "It is God Himself who speaks in the proclamation. Preaching is not talking about God; it is allowing God to talk. The words of the preacher are simply the medium through which the Divine word comes. " 3

Preaching is Christ's life-giving message to humanity. Jesus said to His disciples, "I am the way and the truth and the life" (John 14:6). This means that preaching is proclaiming the Way to Life through the Truth, Jesus Christ.

The apostle Paul clearly speaks of the revealing aspect of preaching: "He brought his word to light through the preaching" (Titus 1:3). He explained, "For since in the

${ }^{1}$ John R. W. Stott, "Biblical Preaching Is Expository Preaching" in Evangelical Roots: A Tribute to Wilbur Smith, ed. Kenneth S. Kantzer (Nashville, TN: Thomas Nelson, 1979), 161 .

${ }^{2}$ Mounce, 152 .

${ }^{3}$ Farmer, 154 . 
wisdom of God the world through its wisdom did not know him, God was pleased through the foolishness of what was preached to save those who believe" ( 1 Cor $1: 21$ ). The Thessalonians "turned to God from idols to serve the living and true God, and to wait for his Son from heaven" (1 Thess 1:9-10) through Paul's preaching. He asserted the reason why they did an about-face: "When you received the word of God, which you heard from us, you accepted it not as the word of men, but as it actually is, the word of God" ( 1 Thess 2:13, emphasis supplied). To the extent that the content of preaching is truly from the word of God, preaching is revelation.

\section{Proclaiming the Gospel Truth}

In preaching, God's gospel is proclaimed. It is not just the communication of Christian ethics. In this light it may be true to say along with Gustaf Wingren, "If . . preaching does not contain the word of the gospel, if it is not the message of God's act, but just talk about Christianity. . then it may well be asked whether it is really preaching at all."1 The gospel is "the power of God for the salvation of everyone who believes" (Rom 1:16).

This gospel is the "gospel of the kingdom" (Matt 24:14), and the "eternal gospel" (Rev 14:6). The apostle Paul declared: "By this gospel you are saved" ( 1 Cor 15:2) .

\footnotetext{
${ }^{1}$ Gustaf Wingren, The Living word (Philadelphia, PA: Muhlenberg Press, 1960), 71.
} 
Paul definitely spoke of the source of the gospel as what he received "by revelation from Jesus Christ" (Gal 1:11, 12). Of this gospel he was "not ashamed" (Rom 1:16). Rather, he felt "the priestly duty of proclaiming the gospel of God" (Rom 15:16).

The gospel is God's act of redemption. Therefore, as Edmund Clowney aptly emphasized, "he who would preach the Word must preach Christ."1 Preaching is proclaiming Christ.

The Impact of Preaching on the History of the Church

Richardson thinks that "if a congregation and preacher underestimate the potential of preaching, both may approach the task of listening and speaking with low expectations." ${ }^{2}$ Unger maintained: "Much of the moral, spiritual and social progress of our day is the direct result of centuries of Christian preaching." ${ }^{3}$ Martyn Lloyd-Jones alleged that "the decadent eras and periods in the history of the Church have always been those in which preaching has declined." 4 Bob Jones, Jr., professed: "Great and decisive preaching has characterized

\footnotetext{
${ }^{1}$ Edmund Clowney, Preaching and Biblical Theology (Grand Rapids, MI: Eerdmans, 1961), 74.

${ }^{2}$ Richardson, 105 .

${ }^{3}$ Unger, 11 .

${ }^{4}$ Martyn Lloyd-Jones, Preaching and Preachers (Grand Rapids, MI: Zondervan, 1972), 24.
} 
every period of growth and revival and power the Church of Christ has experienced. Periods of declension and coldness and defeat have been periods of poor and uninspired preaching." ${ }^{1}$ Frank Colquhoun described the impact of preaching on the history of the Church by saying: "The glorious epochs of evangelical awakening and spiritual advance have been those in which the pulpit has been honored." ${ }^{2}$ Chales Brown states that "the fate of our Protestant Christianity is in my judgment bound up in large measure with the rise and fall of effective preaching." ${ }^{3}$

The Most Important Task Ever Assigned to Man

Ray declares: "The act of preaching is not only the most sacred but the most important task ever assigned to man."4 Mounce reminds us: "The commission to preach, while a solemn trust, is also the greatest honor that can be bestowed upon a man. What other calling elevates man to the role of co-worker with God in the impartation of eternal salvation?"5 That is why the apostle Paul gave this solemn

${ }^{1}$ Bob Jones, Jr., How to Improve Your Preaching (New York: Fleming $\mathrm{H}$. Revell, 1945), 9.

${ }^{2}$ Frank Colquhoun, Christ's Ambassadors (Philadelphia, $\mathrm{PA}$ : Westminster, 1965), 16-17.

${ }^{3}$ Charles R. Brown, The Art of Preachig (New York: Macmillan, 1934), 19.

${ }^{4}$ Ray, 16 .

${ }^{5}$ Mounce, 159 . 
charge to Timothy: "In the presence of God and of Christ Jesus, who will judge the living and the dead, and in view of his appearing and his kingdom, I give you this charge: Preach the Word" (2 Tim 4:1).

Jesus spoke of the task of preaching in the eschatological sense: "This gospel of the kingdom will be preached in the whole world as a testimony to all nations, and then the end will come" (Matt 24:14). The people of God are instructed by the apostle Peter to "look forward to the day of God and speed its coming" (2 Pet 3:12). Responding to the sacred and solemn call to preach in a genuine manner is one of the ways to hasten the day of God.

Jesus' call to preach is also urgent. Nothing is more important than that. One day He said to a man, "Follow me." But the man replied, "Lord, first let me go and bury my father." Jesus said to him, "Let the dead bury their own dead, but you go and proclaim the kingdom of God" (Luke $9: 59,60)$.

According to Douglas White, the apostle Paul also sensed the importance of preaching. He observed that Paul "taught and evidenced in his own ministry that preaching is primary, and all other means must be secondary and supplemental. When other means have become primary the Church has suffered as a result."1 Ray says, compared with

${ }^{1}$ Douglas M. White, The Excellence of Exposition (Neptune, NJ: Loizeaux Brothers, 1977), 15. 
the primary activity of preparing and delivering sermons, "all others combined are incidental." ${ }^{1}$ He adds by an apt description:

Given an unsullied character and real spiritual power in the pulpit, the congregation will forgive weakness anywhere else. . . The cure for the short pastorate and for most of the other troubles in the church is power in the pulpit. . . . If a man is strong in his pulpit, it gives him an irresistible prestige in all phases of church activity, but if he is weak in the pulpit, he is handicapped in every church function to which he puts his hand. ${ }^{2}$

Emil Brunner declared: "Where there is true preaching, where, in the obedience of faith, the word is proclaimed, there, in spite of all appearances to the contrary, the most important thing that ever happens upon this earth takes place." ${ }^{3}$

\section{The Place of the Bible in Preaching}

The appetite of our Christian forefathers for the knowledge of the Bible seemed to be high. But those days are gone. "The average church member today," Unger observes, "is a Biblical illiterate because of a lack of stimulating Bible instruction from the pulpit. People in the pew will not study the Bible if preachers in the pulpit do not study it and preach it." 4

$$
\begin{aligned}
& { }^{1} \text { Ray, } 13 . \\
& { }^{2} \text { Ibid., } 14 .
\end{aligned}
$$

${ }^{3}$ Emil Brunner, Revelation and Reason (Philadelphia, PA: Westminster, 1946), 142 . 
Jones, writing in 1945, described a problem that still exists, in a literal and figurative reference to the Bible: "In many churches.. . the pulpit. . has been put to one side of the building and an altar placed in the center. Rituals have been substituted for reality. There has developed a form of godliness with a denial of its power." ${ }^{1}$ The Word of God has been given a subordinate place. Without biblical preaching, the church becomes largely "a lecture hall for discourses on morality and character building, instead of a meeting place for the public declaration of the divine way of salvation and deliverance from sin." 2 Robinson cuttingly said that "the sacred text serves as an appetizer to get a sermon underway or as a garnish to decorate the message." ${ }^{3}$ He goes on to say that "when a preacher fails to preach the scriptures, he abandons his authority." 4

No generation can have direr circumstances than God prophesied through Amos for Israel: "'The days are coming,' declares the Sovereign LORD, 'When I will send a famine through the land-not a famine of food or a thirst for water, but a famine of hearing the words of the LORD" (Amos $8: 11)$.

\footnotetext{
'Jones, 12 .

${ }^{2}$ Ibid, 30.

${ }^{3}$ Robinson, 25 .

${ }^{4}$ Ibid. , 18 .
} 
The wicked king Zedekiah of Judah brought Jeremiah out of the dungeon and asked him, "Is there any word from the Lord?" (Jer 37:17). Likewise, today; even the godless world expects the preacher to bring some word from the Lord's Word, the Bible." According to Donald Miller, "the only right a man has to stand in a pulpit. . is that he is making an honest effort to bear witness to what he has found in the Bible. For this the Protestant pulpit exists." 2

About Jesus' example of placing the Bible in the right place, Ellen White pointed out:

In teaching these disciples, Jesus showed the importance of the old Testament as a witness to His mission. Many professed Christians now discard the old Testament, claiming that it is no longer of any use. But such is not Christ's teaching. So highly did He value it that at one time He said, "If they hear not Moses and the Prophets, neither will they be persuaded, though one rose from the dead" (Luke $16: 31) .^{3}$

In the time of Jesus there was only the old Testament. The fact that Jesus valued it very highly means that He placed the Bible in its proper place.

Man's word may influence people to a considerable degree; however, it cannot change their hearts. Only the Word of God can do it because of its dynamic capabilities.

${ }^{1}$ Whitesell, 15 .

${ }^{2}$ Donald G. Miller, Fire in Thy Mouth (Nashville, TN: Abingdon, 1954), 41-42.

${ }^{3}$ Ellen G. White, The Desire of Ages (Mountain View, CA: Pacific Press, 1964), 799. 
God's Word and Human Needs

When the preacher prepares a sermon, he prepares his people for healing. As Blackwood said, "Preaching is divine truth voiced by a chosen personality to meet human needs."1 Therefore, as Unger suggests, "humanistic preaching, the heralding of the 'social gospel,' or the proclamation of salvation by character or good works, or any other nonBiblical message, fails to meet the human need."2 Preaching a sermon is to be undertaken so that listeners "may have life, and have it to the full" (John 10:10). This can be accomplished by having the congregation encounter the presence of God. Mounce observed that "the supreme task of the preacher is to lead people into the presence of God." 3 The preacher stands before a group of people "whose one great need is to be ushered into the presence of God."4 Mounce further explains: "If his pulpit has become no more than a platform for religious propaganda, he may either interest or bore his people, depending upon his innate ability, but he will never discharge his sacred obligation to mediate the Divine Presence."5

\footnotetext{
${ }^{1}$ Blackwood, Fine Art, 3.

${ }^{2}$ Unger, 29 .

${ }^{3}$ Ibid., 3 .

${ }^{4}$ Mounce, 158 .

${ }^{5}$ Ibid.
} 
This sense of the encounter with the presence of God happened at Pentecost: "When the people heard this, they were cut to the heart and said to Peter and the other apostles, 'Brothers, what shall we do?'" (Acts 2:37). How could this happen? It was not because Peter's logic was excellent, though it was, but because they had been confronted by God Himself. Farmer said that preaching the Bible is "a divine invasion that confronts man with eternal issues and demands decision."1

In the story of the paralytic let down through the roof and healed by Jesus (Mark 2:1-12), for example, one might be sidetracked by the human interests in "Oriental architecture, paralysis as a type of sin, or the relationship between sin and suffering, and quite neglect the main point of the passage 'that you may know that the Son of Man has authority on earth to forgive sins.'" 2 The preaching which fails to meet the ultimate spiritual needs of the congregation, though it quotes and talks of the Bible in detail, may not be true biblical preaching.

\footnotetext{
${ }^{1}$ Farmer, 155 .

${ }^{2}$ Unger, 26 .
} 
CHAPTER III

THE NATURE OF EXPOSITORY PREACHING

In this chapter how homileticians understand, interpret, and define expository preaching is explored. In addition, criteria for authentic expository preaching are established.

\section{Expository Preaching in Selected Contemporary Literature}

How scholars individually define expository preaching is studied here in selected contemporary literature, and a combined definition of expository preaching is suggested for the purpose of analyzing specific sermons later in this paper.

\section{Definitions of Expository Preaching}

The traditional classification of sermons had its origin a long time ago. The anonymous author of a thirteenth-century document entitled Tractatus de Arte Praedicandi (A Treatise on the Art of Preaching) distinguished three different kinds of preaching: topical, 
textual, and expository. ${ }^{1}$ Some preachers affirm, "I am an expository preacher!" Many Christians say, "We want an expository preacher!" The laity like the term expository because it rings with biblical authority. Yet, asked to define expository preaching, many preachers and laypersons give vague definitions. ${ }^{2}$ A clear and workable definition needs to be established. Robinson says, however, "defining becomes sticky business because what we define we sometimes destroy."3 A small boy dissected a frog to find out what made it jump, but in learning something about the parts he destroyed its life. Preaching is "a living process involving God, the preacher, and the congregation, and no definition can pretend to capture that dynamic."4 An attempt, however, is made in this section to develop a working definition.

There have been many attempts among scholars to define the words expository preaching; much difference of opinion and confusion has resulted. Suggested definitions for expository sermons are noted below.

${ }^{1}$ Warren $W$. Wiersbe and Lloyd M. Perry, The Wycliffe Handbook of Preaching and Preachers (Chicago: Moody, 1984), 45, quoted in Harold T. Bryson, Expository Preaching: The Art of Preaching Through a Book of the Bible (Nashville, TN: Broadman \& Holman, 1995), 12 .

${ }^{2}$ Bryson, 12 .

${ }^{3}$ Robinson, 19 .

${ }^{4}$ Ibid. 
More Than Two Verses

The "More than two verses" definition sees the word expository as treating more than two verses as the text for the sermon. Blackwood explained the meaning of expository preaching by saying: "In the broad sense, this sort of sermon is the unfolding of the truth contained in a passage longer than two or three consecutive verses."1 "Any pulpit message," he adds, "which is based on a fairly long biblical passage is an expository sermon." 2 In a later book, he explained: "Expository preaching means that the light for any sermon comes mainly from a Bible passage longer than two or three consecutive verses. This kind of message differs from a textual sermon chiefly in the length of the Bible passage." ${ }^{3}$ Thus, he stipulates for expository preaching a Bible passage longer than two or three consecutive verses. Douglas White believed: "In distinction to both the topical and textual sermon, the expository sermon is a treatment of a single extended passage of a scripture, a lengthy paragraph, a chapter, or more than a chapter, or even a whole book of the Bible." 4 Hence, this more-than-two-

\footnotetext{
${ }^{1}$ Andrew W. Blackwood, Preaching from the Bible, (Nashville, TN: Abingdon-Cokesbury, 1941), 38.

${ }^{2}$ Ibid, 39.

${ }^{3}$ Andrew W. Blackwood, Expository Preaching for Today: Case studies of Bible Passages (Nashville, TN: Abingdon-Cokesbury, 1953), 13 . 1952), 59 .

${ }^{4}$ Douglas M. White, He Expounded (Chicago: Moody,
} 
31

verses definition sees expository preaching as a sermon dealing with more than two verses for its text.

\section{Connected Series of a Book}

Again, there is a widespread impression that expository preaching works through a Bible book. For instance, William Taylor meant by expository preaching that method of pulpit discourse which "consists in the consecutive interpretation and practical enforcement of a book in the sacred canon."1 F. B. Meyer agrees with William Taylor when he stated: Expository preaching is:

the consecutive treatment of some book or extended portion of scripture on which the preacher has concentrated head and heart, brain and brawn, over which he has thought and wept and prayed, until it has yielded up its inner secret, and the spirit of it has passed into his spirit. ${ }^{2}$

Unger once agreed to this definition by saying: Expository preaching is "at its best when a book is expounded, section by section, in the best homiletical style." ${ }^{3}$ In his recent book, Bryson supports this line of thought by defining expository preaching as "the art of preaching a series of sermons, either consecutive or selective, from a Bible book. " 4

${ }^{1}$ William M. Taylor, The Ministry of the Word (New York: Anson D. F. Randolf, 1876), 155.

${ }^{2}$ F. B. Meyer, Expository Preaching Plans and Methods (New York: George H. Doran, 1910), 29.

${ }^{3}$ Unger, 44 .

${ }^{4}$ Bryson, 39 . 
There may be, however, a practical problem in this definition. If a minister visits a certain congregation only once a month on a circuit, how long would it take him to deal adequately with the Gospel of Matthew? This definition, nevertheless, regards expository preaching as a sermon in a largely consecutive series on a Bible book.

\section{Major and Minor Divisions}

Some scholars emphasize that in expository preaching main and even subpoints need to come from the text. Koller saw that an expository sermon derived "its main points or the leading subhead under each main point from the particular paragraph or chapter or book of the Bible with which it deals." Howington said, "An expository sermon is generally based upon a passage or unit of scripture, and the theme with its divisions and development come from that passage."2 Whitesell also presented a definition of expository preaching in the same Iine. ${ }^{3}$ Thus, this definition claims that if a sermon draws its major and minor divisions from the text, it can be called an expository sermon.

${ }^{1}$ Koller, 21.

${ }^{2}$ Nolan Howington, "Expository Preaching, " Review and Expositor 56 (January 1959): 58 .

${ }^{3}$ Faris D. Whitesell, Power in Expository Preaching (Westwood, NJ: Fleming H. Revell, 1967), vi-vii. 


\section{Verse By Verse}

Meanwhile a view exists that expository preaching is simply a verse-by-verse explanation of a chosen passage.

The sermon by Martin Luther, "The Methods and Fruits of Justification, "1 is one example. John Chrysostom (ca. 347407) used this type in many of his oral presentations. Ulrich Zwingli and John Calvin also preached with a commentary style rather than the rhetorical sermon format. ${ }^{2}$ Hence, this type may have little homiletical unity. David Reed discussed this issue and warned:

The expository sermon is the product of exegesis, but it is in no sense its exhibition. It is not a running commentary upon some passage of Scripture in which its separate parts are taken up verbatim and explained, but, as its name implies, it is a piece of rhetoric: a sermon. It differs from the topical sermon in that it is all derived directly from the Scripture; and it differs from the textual sermon in that more of the details of the scripture passage are employed. ${ }^{3}$

In the verse-by-verse type, if the preacher does not have exceptional gifts, the sermon may be trite, colorless, and rambling and overly cluttered with too many biblical facts. ${ }^{4}$

'The World's Great Sermons, comp. Grenville Kleiser, 10 vols. (New York: Funk \& Wagnalls, 1908), 1:113-143.

${ }^{2}$ Bryson, 21 .

${ }^{3}$ David Reed, Preparing to Preach (New York: George H. Doran, 1911), 387 .

${ }^{4}$ Unger, 40 . 


\section{Explanation Type}

The traditional ranking of topical, textual, and expository sermons, has been as follows: The topical sermon is sometimes biblical but mostly nonbiblical; the textual sermon is biblical but less biblical than the expository; the expository sermon is purely biblical. According to Bryson this can be called a myth. ${ }^{1}$ After all, it raises important questions: How many verses does it take to make a sermon biblical? If a message is not biblical, is it a sermon or a moral address? Thus scholars have come forward who reject the traditional classification of sermons as topical, textual, and expository.

Jay Adams strongly disdains the distinctions among the three by saying: "These distinctions are sheer nonsense and have served mainly to create confusion and have done more harm than good."2 Bryson, as already noted, called the traditional classification of the three, such as topical, textual, and expository, a "homiletical myth" or even "homiletical heresy." ${ }^{3}$ Clyde Fant, William Thompson,

${ }^{1}$ Bryson, 27.

${ }^{2}$ Jay E. Adams, Essays on Biblical Preaching (Grand Rapids, MI: Zondervan, 1983), 7 .

${ }^{3}$ Bryson, $26-29$. 
Leander Keck, and Neil Richardson are in agreement on this point. ${ }^{1}$

John stott was concerned about the idea that sermons should be classified as more biblical and less biblical by saying that whatever the length of the text is, "still the truly Christian preacher is an expositor."2 He suggested the direction of the definition of expository preaching by stating: "It refers to the content of the sermon (biblical truth) rather than its style (a running commentary)." 3 That is to say that in defining expository preaching, emphasis should be given to the content more than to the format. Thus, the explanation type arises.

This type views the words expository preaching as the idea of explaining the text. The word expository comes from the Latin word exponere. It means "to put on display."4 In late Latin (A.D. 180-600), the word exponere came to mean "to interpret or explain." 5 John Calvin used the term exposition in the idea of explaining scripture.

${ }^{1}$ Clyde E. Fant, Preaching for Today, rev. ed. (New York: Harper \& Row, 1975), 100-101; William D. Thompson, Preaching Biblically: Exegesis and Interpretation (Nashville, TN: Abingdon, 1981), 9-10; Leander Keck, The Bible in the Pulpit (Nashville, TN: Abingdon, 1978), 26; Richardson, 35 .

${ }^{2}$ John R. W. Stott, Between Two Worlds: The Art of Preaching in the Twentieth Century (Grand Rapids, MI: Eerdmans, 1982), 168 .

$$
\begin{aligned}
& { }^{3} \text { Ibid., 125-126. } \\
& { }^{4} \text { Bryson, } 15 . \\
& { }^{5} \text { Ibid. }
\end{aligned}
$$


John Leith stated that Calvin had understood exposition as the explication and application of scripture. ${ }^{1}$

Ray believes that "in preaching, exposition is the detailed interpretation, logical amplification, and practical application of a passage of scripture."2 Likewise, Harold Knott said that the expository sermon is "an effort to explain, illustrate, and apply the scriptures to life." 3 Long ago, Broadus advocated this type by saying:

An expository discourse may be defined as one which is occupied mainly, or at any rate very largely, with the exposition of scripture. . . It may be devoted to a long passage, or a very short one, even part of a sentence. It may be one of a series, or may stand by itself. ${ }^{4}$

Phelps argued that a sermon is expository if the chief object of the sermon is explanation. ${ }^{5}$ Marvin Vincent wrote: "Exposition is exposing the truth contained in God's

'John H. Leith, "Calvin's Doctrine of the Proclamation of the Word and Its Significance for Today in the Light of Recent Research," Review and Expositor 86 (Winter 1989): 32, 34 .

${ }^{2}$ Ray, 11 .

${ }^{3}$ Harold E. Knott, How to Prepare an Expository Sermon (Cincinnati, OH: Standard Publishing, 1930), 11.

${ }^{4} \mathrm{John}$ A. Broadus, A Treatise on the Preparation and Delivery of Sermons, 7 th ed. (New York: A. C. Armstrong and Son, 1891), 303 .

${ }^{5}$ Austin Phelps, The Theory of Preaching (New York: Charles Scribner's Sons, 1894), 34. 
Word: laying it open; putting it forth where the people may get hold of it."1 Years later, Unger suggested:

No matter what the length of the portion explained may be, if it is handled in such a way that its real and essential meaning as it existed in the mind of the particular biblical writer and as it exists in the light of the over-all context of scriptures is made plain and applied to the present-day needs of the hearers, it may be properly be said to be expository preaching. ${ }^{2}$

\section{As Whitesell pointed out, "the length of the}

Scripture text is not the main criterion in expository preaching, but rather the way the passage is handled." ${ }^{3}$ stott also emphasized that "the size of the text is immaterial, so long as it is biblical."4 In expository preaching, as stott aptly described, the biblical text is "neither a conventional introduction to a sermon on a largely different theme, nor a convenient peg on which to hang a ragbag of miscellaneous thoughts, but a master which dictates and controls what is said." 5

The explanation type emerges from this review as the preferred model.

${ }^{1}$ Marvin Vincent, The Expositor in the Pulpit (New York: Anson D. F. Randolf, 1884), 6. R. Ames Montgomery voiced the same idea in Expository Preaching (Westwood, NJ: Fleming $H$. Revell, 1939), 42 .

${ }^{2}$ Unger, 33 .

${ }^{3}$ Whitesell, The Art of Biblical Preaching, 53.

${ }^{4}$ Stott, 126 .

${ }^{5}$ Ibid. 
Homiletical Freedom

This definition of exposition as "explanation" seems in a sense to give freedom to a pulpit expositor from slavish conformity to format, theories, and rules. Many scholars join the idea that a preacher should not be confined to only one method. Blackwood said, "The emphasis is upon the freedom of the pulpit expositor to deal with the Bible as seems to him best in view of his own ability and his people's highest welfare. Let him never submit to bondage under any theory of preaching."I Bryson pointed out: "Such an overemphasis on technique can cause preoccupation with form rather than content. Homiletical rules are not to be arrogant masters but helpful friends for preparing and delivering biblical content." 2 Furthermore, he strongly challenges rigidity by stating:

No technique in homiletics should be infallible. Every theoretical proclamation idea needs to be questioned with regard to its validity and practicality. The demythologization process needs to be a constant process. . . . The time has come to look at expository preaching in a new way so the expression can be used with understanding, respect, and practicality. ${ }^{3}$

Unger warned: "It is a mistake to impose too narrow a definition upon expository preaching." 4 While a series of

\footnotetext{
${ }^{1}$ Blackwood, Preaching from the Bible, 40.

${ }^{2}$ Bryson, 31 .

${ }^{3}$ Ibid., 33.

${ }^{4}$ Unger, 48 .
} 
sermons expounding some book or books of the Bible is undoubtedly an important method of expository approach, it is not the only one. Moreover, he continued: "The tendency closely to confine pulpit exposition inevitably leads to monotony of treatment, discouragement in the cultivation of the expository method and eventual abandonment of it altogether."I Expository preaching, as Robinson described,

at its core is more a philosophy than a method. Whether or not a man can be called an expositor starts with his purpose and with his honest answer to the question: "Do you, as a preacher, endeavor to bend your thought to the scriptures, or do you use the Scriptures to support your thought?" ${ }^{2}$

To conclude the discussions thus far, expository preaching can be defined, in a preliminary way, as the art of preaching the word of God through the explanation of a definite Bible text and the application of its meaning to people's needs today.

\section{Criteria for an Expository Sermon}

In this section the hermeneutical principles and homiletical rules, which help distinguish expository preaching with the intent of establishing appropriate criteria by which to evaluate preaching as "expository," are reviewed.

${ }^{1}$ Ibid.

${ }^{2}$ Robinson, 20 . 
Hermeneutical Principles

The term hermeneutics "is in disfavor among some contemporary scholars who argue that it is no more than theological jargon for interpretation."1 Gerhard Ebeling ${ }^{2}$ and C. F. Evans, ${ }^{3}$ for example, think of interpretation and hermeneutics as being the same. However, P. J. Achtemeier says that "hermeneutics formulates rules and methods to get from exegesis to interpretation."4 Exegesis is "the historical investigation into the meaning of the text."5 It is "the foundation of all truly biblical interpretation."6 Thus, exegesis and interpretation both play an important role in hermeneutics and the construction of a sermon.

For some axioms of Bible interpretation, Roy Zuck states as follows: ${ }^{7}$

${ }^{1}$ Anthony C. Thiselton, The Two Horizons (Grand Rapids, MI: Eerdmans, 1980), 10 .

${ }^{2}$ Gerhard Ebeling, word and Faith, trans. James W. Leitch (London: SCM Press, 1963), 321.

${ }^{3}$ C. F. Evans, Is Holy Scripture Christian? (London: SCM Press, 1971), 33.

${ }^{4} \mathrm{P}$. J. Achtemeier, An Introduction to Hermeneutics (Philadelphia, PA: Westminster, 1969), 13, 14.

${ }^{5}$ Gordon D. Fee, New Testament Exegesis (Philadelphia, PA: Westminster, 1983), 21 .

${ }^{6}$ Bernard Ramm, Hermeneutics (Grand Rapids, MI: Baker, 1971), 7, 8 .

${ }^{7}$ Roy B. Zuck, Basic Bible Interpretation (Wheaton, IL: Victor Books, 1991), 61-74. 
Because the Bible is a human book:

1. Each biblical writing - that is, each word, sentence, and book-was recorded in a written language and followed normal, grammatical meanings, including figurative language.

2. Each biblical writing was written by someone to specific hearers or readers in a specific historical, geographical situation for a specific purpose.

3. The Bible is affected and influenced by the cultural environment from which each human writer wrote.

4. Each biblical writing was accepted or understood in the light of its context.

Also, because the Bible is a divine book:

1. The Bible is inerrant.

2. The Bible is authoritative.

3. The Bible has unity.

4. The Bible has mystery.

In applying a hermeneutical strategy to preaching,

Norval Pease suggests seven guiding principles: ${ }^{1}$

1. The sola scriptura principle (This means all preaching must be biblical preaching. It should have a text or passage to be analyzed with the natural division of the text and the theological implication of the passage.)

${ }^{1}$ Norval F. Pease, "Hermeneutical Principles Applied to Preaching" in A Symposium on Biblical Hermeneutics, ed. Gordon M. Hyde (Washington, DC: Review and Herald, 1974), 257-261. 
2. The unity of Scripture principle (It means, for example, that there is no basic disagreement between the theology of Paul and the theology of James. The same Holy Spirit guided all the Bible writers; therefore, despite their individual differences, a fundamental oneness persists.)

3. The "Let Scripture explain Scripture" principle (The preacher must be willing to scuttle a "brilliant" preaching idea if he discovers it to be out of harmony with the real meaning of the text in the context of parallel or explanatory passages.)

4. Proper interpretation of biblical words and sentences (For example, the word faith may mean "saving faith" in the highest Christian sense; it may mean "assenting to an idea"; it may refer to faithfulness. As many as six different meanings of faith have been detected in Paul's epistle to the Romans.)

5. The context and historical background (The preacher must be aware of the author, the circumstances of writing, the time and place of writing, and the reason for writing. This information may not be made obvious in the sermon, but it needs to be part of the preacher's equipment as he prepares his sermon. Horrible blunders have been made by preachers who neglected the contextual and historical background of the Bible.) 
6. The message of the Bible to be interpreted literally unless it is obviously figurative (Many a preacher has succumbed to the temptation to depend too much on allegory. One of the accomplishments of the Protestant Reformation was the shattering of the allegorical method of biblical interpretation that had been popular for centuries. The preacher has the right to draw lessons from biblical passages. He may freely say, "This text suggests . . " or, "This passage may be applied . . ." But when he says, "This text means. . ." he had better stay close to the literal meaning intended by the writer. For the interpretation of figurative expressions such as the symbols of prophecy, the safest procedure is to look for a clear statement from another inspired author. Preachers must exercise unusual care that they do not mislead their listeners by fanciful and unsupported interpretations.)

7. The correct use of the typological principle. Typology is a legitimate approach to biblical interpretation. Many sermons have been preached by Seventhday Adventist preachers using passages from the Epistle to the Hebrews to unlock the mysteries of the old Testament sanctuary service. This need not be unsafe allegory or undue spiritualizing. It is, rather, a process of recognizing the type (generally old Testament) that finds its counterpart in the New Testament antitype. Preachers get into trouble when they use their imagination too freely 
in this area. Inferences must be supportable by reasonable evidence. Unsound analogies must not be used. "Private interpretations" shake people's faith in the preacher and, more tragically, in the Bible itself.

Many a preacher thinks that he is exempt from close adherence to the rule of exegesis. However, Bernard Ramm states:

Proper exegesis is necessary for commentators and theologians but preachers-it is argued-have a "poetic license" with reference to Scripture. This is most unfortunate reasoning. If the preacher's duty is to minister the Word of God, hermeneutics is the means whereby he determines the meaning of the Word of God. To ask for exemptions from the strict rules of hermeneutics is then to ask for an exemption from preaching the true meaning of the Word of God. This is precisely a repudiation of what a man is called to preach, namely, the truth of God's Word. This does not mean that preaching is nothing but public exegesis or drab commenting on the Sacred Text. There must be energy, life, imagination, relevancy, illustration, and passion to all preaching. Bookish, dry, technical exposition is not necessarily preaching the Word of God. But whenever Scripture is used, it must be used according to sound rules of hermeneutics. ${ }^{1}$

Sound hermeneutics "should enhance the preacher's sermons. His messages should be more interesting, more authentic, more appealing, because they reflect more adequately the message of the Scriptures." ${ }^{2}$

${ }^{1}$ Bernard Ramm, Protestant Biblical Interpretation, 3 rd rev. ed. (Grand Rapids, MI: Baker, 1970), 197.

${ }^{2}$ Pease, 260 
Homiletical Rules

Preaching is also governed by homiletical rules.

The information and contents found through the exegesis and interpretation of a text become a sermon when they are explained, illustrated, and applied in a relevant and compelling way. ${ }^{1}$ Scholars have suggested the following as important elements in the development of sermons:

1. Explanation. Every truth from the text should be explained. It is perhaps the most fundamental element of expository preaching.

2. Illustration. Whitesell even says, "A sermon is virtually worthless without good illustrations."2

Illustrations help hearers (a) understand the truth more easily, (b) remember it more easily and longer, and (c) get a break in listening so that they can listen to the next content with refreshed attention.

3. Application. This brings the hearers "into divine encounter. . . . It turns a sermon into a message."3 H. C. Brown Jr. affirms that "as explanation presents the message of God 'then,' so application presents the message

${ }^{1}$ Ramon Araujo C., "A Biblical Preaching strategy for the Ministers of the Seventh-day Adventist Central Dominican Conference," D.Min. project report, Andrews University, 1987, 53.

${ }^{2}$ Whitesell, Power in Expository Preaching, 75.

Ibid., 91,92 . 
of God 'now." 1 It makes the hearer say, "He is speaking to me."2 Whitesell adds that "biblical truth is meaningless unless it bears on life. What the text says is not said before people, but to people." ${ }^{3}$ This is the most important stage of the sermon.

Whitesell restates and adds to the above rules for an expository sermon in the following summary:

1. It is based on a passage in the Bible, either short or long.

2. It seeks to learn the primary, basic meaning of that passage.

3. It relates that meaning to the context of the passage.

4. It digs down for the timeless, universal truths stemming out of the passage.

5. It organizes these truths tightly around one central theme.

6. It uses the rhetorical elements of explanation, argument, illustration, and application to bring the truth of the passage home to the hearer.

7. It seeks to persuade the listener to obey the truth of the passage discussed. ${ }^{4}$

Whitesell completes his list of rules by identifying what expository preaching is not:

1. It is not running commentary from word to word and verse to verse without unity, outline, and persuasive drive. ${ }^{5}$

${ }^{1} \mathrm{H}$. C. Brown Jr., A Quest for Reformation in Preaching (Waco, TX: Word, 1968), 60 .

${ }^{2}$ Whitesell, Power in Expository Preaching, 91-92.

${ }^{3}$ Ibid.

${ }^{4}$ Ibid., xv.

${ }^{5} \mathrm{Knott}$ and Thompson also voiced concerns about this: Knott, 19; William D. Thompson, A Listener's Guide to Preaching (Nashville, TN: Abingdon, 1966), 21. 
2. It is not rambling comment and offhand remarks about the passage apart from thorough exegesis and logical order.

3. It is not a mass of disconnected suggestions and inferences based on the surface meaning of the passage but not sustained by a depth-and-breadth study of the text.

4. It is not pure exegesis, no matter how scholarly, if it lacks theme, thesis, outline and development.

5. It is not a mere structural outline of the passage with a few supporting comments but lacking other rhetorical and sermonic elements.

6. It is not a topical homily using scattered parts of the passage but omitting discussion of other equally important parts.

7. It is not a chopped-up collection of grammatical findings and quotations from commentaries without being fused together into a smooth, flowing, interesting and compelling message.

8. It is not a Sunday-school-lesson discussion of a Bible passage organized around a contents outline, informal and fervent, but lacking sermonic structure and rhetorical factors.

9. It is not a Bible reading which links together a number of scattered Bible passages around a common theme but does not deal with any of them in a thorough, grammatical and contextual manner.

10. It is not the ordinary devotional or prayermeeting talk which combines running commentary, rambling remarks, disconnected suggestions, and personal reactions into a seminspirational discussion, but without the benefit of exegetical-contextual study and the persuasive elements of a sermon. ${ }^{1}$

\section{Summary of Expository Criteria}

When all of this discussion from selected

contemporary literature is synthesized, the broadly accepted criteria for an expository sermon can be identified as follows :

\footnotetext{
${ }^{1}$ Ibid., vii-viii.
} 
1. It is based on a single governing biblical passage. The text provides a leading thought from divine guidance.

2. It is based on an exegetical analysis of the text.

3. It is based on a right interpretation and persuasive explanation of the text.

4. It is Christ-centered. The Word of God testifies to Jesus Christ (John 5:39). Preaching is proclaiming God's act of redemption in Jesus Christ.

5. It is illustrated. The preacher must make the content of the text easy for ordinary people to understand. Illustrations-as windows-bring in light, and help people see the beauty of truth with clarity and freshness.

6. It applies the truth of the passage to the hearer's present needs. Here the Spirit of Christ works with life-giving transforming power. 
CHAPTER IV

THE NEED FOR EXPOSITORY PREACHING

In this chapter a case is made for the use of expository preaching as a primary method. I will first look at three hindrances that have kept this need from being fully realized. Next, the advantages of expository preaching are discussed. Finally, a study of expository preaching in the New and old Testaments is undertaken to show that preaching's expository roots are biblical.

\section{The Three Factors of Expository Preaching}

As mentioned earlier, there has been a tendency to use the Bible as a springboard from which to jump into a discussion of one's own thoughts. As Unger noticed, "it is one thing to utilize the Bible as a source book to furnish the content of the message. It is quite another thing to employ it as a mere 'textual repository' to supply germinal ideas to develop human impressions and opinions." ${ }^{1}$ Whether there is a faithful exposition of a text or not may be one of the variables in this difference.

\footnotetext{
${ }^{1}$ Unger, 12 .
} 
The reality, however, is that the "topical" sermon"

is prevailing. Howington stated that in his day

an examination of published sermons will indicate the fact that much of our American preaching is topical, or at the best, textual-topical. Even within the Bible belt, among Southern Baptists who claim the scriptures as their basic authority in matters of faith and practice, there are few expository preachers. ${ }^{2}$

The same situation seems to exist today. Preachers often avoid authentic expository preaching. Some of the reasons for this have been suggested by numerous scholars over the years; I term them "hindrances":

1. Expository preaching is "difficult and requires equipment and hard study."3

2. Expository preaching "has been brought into disrepute in some quarters because it has occasionally been misrepresented." 4

${ }^{1}$ According to whitesell, "In this method the preacher follows a topic or subject as his controlling principle." Whitesell, Power in Expository Preaching, 44. Thus, a topical sermon is a sermon in which the major and minor divisions are derived from the topic or the subject. About the textual sermon, Whitesell says: In this method, "a Bible text becomes the controlling factor in the organization and development of the sermon." Ibid., 48 . Hence, a textual sermon is the sermon whose major and minor divisions are derived from the text, which usually consists of one or two verses.

${ }^{2}$ Howington, 56 .

${ }^{3} \mathrm{~W}$. O. Carver, out of His Treasures (Nashville, TN: Broadman, 1956), 48 .

${ }^{4}$ Unger, 35. He adds: "The teaching of the Bible in a purely analytical and abstract way, divorced from spiritual power and passion and unaddressed to human need, has paraded as preaching of the Bible. But teaching. . . is not 
51

3. Many "lack knowing how." I Ministers lack "the training and the time for a mastery of the method."2

Nevertheless, many consider expository preaching "a superior type." ${ }^{3}$ Carver held that expository preaching is "most rewarding if faithfully done. Our churches and denomination are in great need of it." 4 About the limitation of topical preaching, Brooks observed:

The preaching that is the discussion of a topic may be interesting, but it grows unsatisfactory because it does not fasten itself to the authority of

Scripture. It tempts the preacher's genius and invention, but is apt to send people away with a feeling that they have heard him more than they have heard God. 5

Douglas White discussed a number of brief paragraphs by pastors, some of whom served as professors of homiletics or as church executives, and summed up:

Expository preaching is the best. Our preachers are so busy in promotional work that they are not giving the time necessary for expository preaching. People are hungry for it. It is very rare these days, and the Church is paying a high price for lack of a constructive, all-round Bible teaching ministry. It

expository preaching, if it does not bring the word of God down to the plane where men live and with the unction and power of the Holy spirit challenge them with its claims." Ibid.

${ }^{1}$ Douglas M. White, 13-15.

${ }^{2}$ Howington, 57.

${ }^{3}$ Howington discussed a survey of ministers with respect to their homiletical preferences and practices, as mentioned above.

${ }^{4}$ Carver, 48 .

${ }^{5}$ Brooks, 130 . 
is the most valuable type of preaching for building up an intelligent and spiritual church. In my opinion this is the most effective preaching to be done. ${ }^{1}$

With this comment, I fully agree!

\section{The Advantages of Expository Preaching}

Scholars enumerate the following features as the advantages of expository preaching: ${ }^{2}$

1. Expository preaching best achieves the biblical intent of preaching: delivering God's message.

2. Expository preaching promotes scripturally authoritative preaching.

3. Expository preaching magnifies God's Word.

4. Expository preaching provides a storehouse of preaching material. Knott says that a preacher who preaches from the Bible "will never be wanting either the subject of a sermon or the congregation." 3 In comparison with the topical method, which develops the proposition from outside sources, Knott continued by saying that the preacher need "never rack his brain, or roam the streets for something to say and something to the point. The stream is perennial.

${ }^{1}$ Douglas M. White, 13-15.

'John MacArthur, Jr., and the Master's Seminary Faculty, Rediscovering Expository Preaching (Dallas, TX: Word, 1992), 20; also R. Ames Montgomery, 36-54; Blackwood, Expository Preaching for Today: Case Studies of Bible Passages, 27-43; Meyer, 49-62; Taylor, 161-179.

${ }^{3}$ Knott , 21 . 
It is the river of the water of life."1 The expository preacher will be more and more amazed at the wonders of the Bible and, as Unger affirmed, will "find himself possessed of an ever-increasing store of thrilling and heart-warming truth which will furnish the basis of more sermons than he could preach in a lifetime." 2

5. Expository preaching leads to thinking and living biblically. It "gradually develops both in the pulpit and in the pew the Scriptural point of view, than which there is none better." ${ }^{3}$ The result is that the pastor and his or her members together become grounded in Scripture.

6. Expository preaching encourages both depth and comprehensiveness.

7. Expository preaching discourages the insertion of human ideas.

8. Expository preaching awakes an interest in the study of the Scriptures. As Knott expressed it, this is true "if it can be shown that the Bible throws light upon the problems of life. Nothing is more needed in our day than an awakened interest in the Bible. It is the hope of our civilization." 4

${ }^{1}$ Ibid. , 6 .

${ }^{2}$ Unger, 27 .

${ }^{3}$ Brown, 44.

${ }^{4}$ Knott, 17 . 
9. Expository preaching can produce truly

regenerated and spirit-filled men and women, aggressive in the work of God and joyous in Christian fellowship. ${ }^{1}$

10. Expository preaching makes it easy to introduce topics that are unwelcome. About this feature Ray explains :

If in a topical sermon, the preacher gives an admonition or administers a rebuke, the subjects of it will become offended, saying that he went out of his way to criticize them. But if he finds the same thing in the course of an exposition of scripture, they cannot be offended on the ground that he lugged it in. They will see that there it is in the scripture, and the preacher could not consistently go around it, and they will gladly acquit him of being offensively personal. The probabilities are they will be helped by that type of admonition or rebuke, but they will be hurt by the other method. ${ }^{2}$

Some preachers, Knott explains,

find a difficulty in giving messages on finances, missions, Jesus' teaching on marriage, and similar themes. To give a topical sermon on any of these subjects may sometimes be embarrassing, but if one is giving the exposition of a scripture in which these subjects are an integral part, he can introduce them as a step in the development of his theme. ${ }^{3}$

11. It lends itself to sermon series.

Some scholars argue that expository preaching is the art of "preaching a series of sermons, either consecutive or

${ }^{1}$ Unger, 29.

${ }^{2}$ Ray, 50 .

${ }^{3}$ Knott, 17 . 
selective, from a Bible book."I Some advantages of series sermons are:

1. The well-arranged series of sermons will oftentimes change casual into regular attendants and $\mathrm{fix}$ them in that more wholesome habit.

2. The series will strengthen the habit of seeing all truths in their relation to other cognate truths and in right perspective.

3. It will enable the preacher to utilize the results of some special line of reading which he has been pursuing for an entire season.

4. It will help to save the preacher from the skittering, promiscuous way of presenting religious truth. Knott quoted Dean Brown as saying that expository preaching had "the historic warrant of being apostolic."2 In addition, Douglas White asserted that the conclusion that expository preaching will enable the minister to magnify his office more nobly and efficiently than any other method was not merely his private opinion but had been "substantiated by the testimony of Christian leaders through the centuries, as well as by evangelical contemporaries." ${ }^{3}$

${ }^{1}$ One of them is Harold $T$. Bryson. The definition mentioned above is his in his book, Expository Preaching: The Art of Preaching Through a Book of the Bible, 39 .

${ }^{2}$ Dean Brown, quoted in Knott, 12 .

${ }^{3}$ Douglas M. White, 16 . 
It would be fatuous, however, to assume that everyone agrees with these statements. As Robinson pointed out, "while most preachers tip their hats to expository preaching, their practice gives them away. Since they seldom do it, they too vote no."1 One of the reasons is, as discussed before, that expository preaching has occasionally been misrepresented. It includes poor exposition and application to the hearers' need. People do not come to church in order to know what happened to the Hittites. The preacher should start with "the auditor's vital need, and throw all the light he can on that." 2

Another reason is that many lack knowledge to do it. This is why chapter 5 is given to finding out what is going on among Korean Adventist pastors in preaching, and Appendix is allocated to the development of a model for a course in expository preaching for pastors and theology students.

In this postindustrial society in which many men and women want information and intellect and intelligence, the Christian pulpit should reinstate the authority and power of the word of God. What Whitesell shared fifty years ago about a minister's experience of expository preaching is still true:

After ten years of topical, textual, doctrinal, and general preaching, I have spent the past three years in expository preaching entirely, with these

\footnotetext{
${ }^{1}$ Robinson, 19 .

${ }^{2}$ Knott , $18-19$.
} 
results: More souls have been saved, more improvements have been made to church properties, and more money has been given to missionary causes than in any similar period in the church's history; and it was God, working through His Word, that did it all. ${ }^{1}$

Expository preaching works. Its fruit is real. Today many churches are dying. A number of church members are suffering from the dearth of the word of God. It is possible that if more Christian pulpits adopt expository preaching, many will have life, and have it to the full.

\section{It Returns Preaching to Its Expository Roots}

Preaching has its expository roots in the scripture. This is another reason supporting the need for expository preaching. In this section a study is made of expository preaching in the Old and New Testaments.

Expository Preaching in the Old Testament

Concerning expository preaching in the old Testament times, Robert Dabney said: "It was under Ezra that preaching assumed, by divine appointment, more nearly its modern place as a constant part of worship, and also its modern character as an exposition of the written Scriptures."2 Neh 8 explains the pattern:

All the people assembled as one man. . . They told Ezra the scribe to bring out the Law of Moses, which

\footnotetext{
${ }^{1}$ Whitesell, Power in Expository Preaching, 56.

${ }^{2}$ Robert L. Dabney, Sacred Rhetoric: Or a Course of Lectures on Preaching (Carlisle, PA: Banner of Truth, 1979), 23 .
} 
the LORD had commanded for Israel. So on the first day of the seventh month Ezra the priest brought the Law before the assembly, which was made up of men and women and all who were able to understand. He read it aloud from daybreak till noon. . . . And all the people listened attentively to the Book of the Law. Ezra the scribe stood on a high wooden platform built for the occasion. . . . Ezra opened the book. All the people could see him because he was standing above them; and as he opened it, the people all stood up. . . The Levites. . . instructed the people in the Law while the people were standing there. They read from the Book of the Law of God, making it clear and giving the meaning ${ }^{1}$ so that the people could understand what was being read. (Neh $8: 1-8$ )

From the record quoted above, it can be said that

the following characteristics of modern expository preaching are present:

1. The people were assembled.

2. Ezra, the scribe and priest, brought out the Word of God (the Book of the Law of Moses).

3. He stood on a high wooden platform built for the occasion, where all the people could see him.

4. It was on an appointed day for worship.

5. Ezra and the Levites clearly read the Book of the Law of God, and gave the meaning, a work of exposition, making the message clear to the people.

Nehemiah 9 tells that "they stood where they were and read from the Book of the Law of the LORD their God for a quarter of the day" (9:3). The rest of the chapter is given over to "a historical exposition of the mercy and

\footnotetext{
'The RSV reads, "and they gave the sense."
} 
goodness of God to Israel in days past."1 Douglas White continues:

It seems to have been the method employed throughout the centuries prior to the coming of the christ, and -though corrupted with tradition and spiritual blindness, and thus lacking authority and powerwas still in vogue when Jesus entered His pubic ministry. ${ }^{2}$

\section{Expository Preaching in the New Testament}

In this section the preaching of Jesus, Peter, and Paul is analyzed so that appropriate implications may be drawn in support of contemporary expository preaching.

\section{Jesus' Preaching}

Jesus Christ, as James Hoppin and many others have observed, "preached from the old Testament as His text." 3 One of the notable examples of public exposition by Jesus is recorded in Luke 4:16-21:

He went to Nazareth, . . . and on the Sabbath day he went into the synagogue, as was his custom. And he stood up to read. The scroll of the prophet Isaiah was handed to him. Unrolling it, he found the place where it is written: "The spirit of the Lord is on me, because he has anointed me to preach good news to the poor. He has sent me to proclaim freedom for the prisoners and recovery of sight for the blind, to release the oppressed, to proclaim the year of the Lord's favor." Then he rolled up the scroll, gave it back to the attendant and sat down. The eyes of everyone in the synagogue were fastened on

\footnotetext{
${ }^{1}$ Douglas M. White, 18 .

${ }^{2}$ Ibid.

${ }^{3}$ James M. Hoppin, Homiletics (New York: Funk \& Wagnalis, 1883), 29.
} 
him, and he began by saying to them, "Today this scripture is fulfilled in your hearing."

Here the factors of expository preaching can be seen:

1. Jesus used the biblical text (Isa 61:1-2a).

2. He interpreted and explained the word. "All spoke well of him and were amazed at the gracious words that came from his lips" (Luke 4:22).

3. He applied the word to His hearers. He said, "Today this scripture is fulfilled in your hearing" (vs. 21). He Himself is the Messiah. Ellen White aptly described that Jesus' preaching at Nazareth was expository: ${ }^{1}$

When a rabbi was present at the synagogue, he was expected to deliver the sermon, and any Israelite might give the reading from the prophets. . . . He "stood up to read. . . ." Jesus stood before people as a living expositor of the prophecies concerning Himself. Explaining the words He had read, He spoke of the Messiah (emphasis supplied).$^{2}$

The disciple Mark says: "He preached the word to them" (Mark $2: 2)$. His was, as Douglas M. White stated,

no cursory, mechanical repetition, but a powerful heart-searching interpretation and application of the truth, designed to convince His hearers of their need of a personal relationship to God through Him, and of His right to claim their faith and allegiance for Himself (emphasis supplied). ${ }^{3}$

${ }^{1}$ Not all of Jesus' preaching was expository (Luke 6, for example). However, He used the method as a crucial tool.

${ }^{2}$ Ellen G. White, The Desire of Ages, 236, 237.

${ }^{3}$ Douglas M. White, 19. 
On the road to Emmaus, in His final expository proclamation before the ascension, "beginning with Moses and all the Prophets, he explained to them what was said in all the Scriptures concerning himself" (Luke 24:27, emphasis supplied). Thus, Christ, as Ellen G. White wrote, "discoursed to His disciples, opening their minds that they might understand the Scriptures"1 (emphasis supplied). She commented:

Had He first made Himself known to them, their hearts would have been satisfied. In the fullness of their joy they would have hungered for nothing more. But it was necessary for them to understand the witness borne to Him by the types and prophecies of the Old Testament. Upon these their faith must be established. Christ performed no miracle to convince them, but it was His first work to explain the scriptures (emphasis supplied).2

Afterward they asked each other, "were not our hearts burning within us while he talked with us on the road and opened the Scriptures to us?" (Luke 24:32, emphasis supplied). It was Jesus' exposition of the Scriptures that made them go out immediately that same night and return at once to Jerusalem with a glowing testimony. Jesus Christ is our "ideal Preacher." ${ }^{3}$

Mark 1:14, 15 gives another example. It reads, "Jesus went into Galilee, proclaiming the good news of God.

\footnotetext{
${ }^{1}$ Ellen G. White, The Desire of Ages, 800 .

İbid. , 798-799.

${ }^{3}$ Blackwood, preaching from the Bible, 16 .
} 
'The time has come,' he said. 'The kingdom of God is near. Repent and believe the good news!" "It can be analyzed as follows :

1. The sentence "The time has come" can mean that the prophecies are fulfilled. It was based on the Scriptures, exegesis, and interpretation of the biblical passages.

2. The sentence "The kingdom of God is near" may be based on His ministry because He represents the kingdom of God as King.

3. The sentence "Repent and believe the good news" may be the application based on the people's present needs. Thus, it can be said that Jesus' preaching included these elements:

1. The old Testament Scriptures

2. Exegesis and interpretation of the biblical passages

3. Christo-centric message

4. Explanation

5. Illustration

6. Application to the hearers' present needs.

Peter's Preaching

In a broader sense, says Kerr, "apostolic preaching began on the Day of Pentecost."1 In the book of Acts,

${ }^{1}$ Hugh Thompson Kerr, Preaching in the Early Church (New York: Fleming $H$. Revell, 1942), 14. 
there are recorded four sermons by Peter, one by stephen, and seven by Paul. ${ }^{1}$

Peter's first expository preaching was on the Day of Pentecost. It was an exposition of passages from the prophecy of Joel and from the book of Ps (Acts 2:14-40). It can be outlined as follows:

1. Interpretation of Joel $2: 28-32$ and Ps $16: 8-11$ (vss. $14-21,26-35$ )

2. The person and work of Jesus Christ (vss. 22-24)

3. Origin of Jesus through the line of David (vss. $26-30)$

4. Emphasis on the kerygmatic ingredient of the resurrection and exaltation in power (vss. 31-37)

5. Application of the message to the hearers because they crucified the Lord (vs. 38).

His second sermon was occasioned by the healing of the lame man at the Beautiful Gate (Acts 3:12-26). As Mounce explained, "Peter preached: It was through the resurrection that God had glorified His Servant. He continues to glorify Him by demonstrating the power of His name. Faith in His name has effected this astonishing cure." ${ }^{2}$ Then Peter makes a plea for repentance. But he never finished his speech. The priests and sadducees were

${ }^{1} D$. W. Cleverley Ford, The Ministry of the Word (Grand Rapids, MI: Eerdmans, 1979), 54 .

${ }^{2}$ Mounce, 73 . 
greatly disturbed at the proclamation of the resurrection of Jesus and arrested Peter and John.

Peter's next recorded sermon takes place on the following day (Acts $4: 8-12,19 b-20$ ). And his final recorded sermon is presented at the house of Cornelius (Acts 10:3443). Peter's words to Cornelius are based on the message God gave Israel concerning Jesus (Acts 10:36-43).

The theme of Peter's preaching was that "God has made Jesus both Lord and Messiah through His being raised from the dead by the Father."1 This is clear when Peter's first preaching is analyzed. ${ }^{2}$

1. The prophecies have been fulfilled (Acts $2: 36$ ). "This is how God fulfilled what he had foretold through all the prophets" (Acts 3:18). "All the prophets from Samuel on, as many as have spoken, have foretold these days" (Acts $3: 24)$. About the new dimension in Peter's address on the Day of Pentecost, Dewitte Holland said: "No longer was it necessary to say that the kingdom of God was at hand, the apostles now could proclaim that the kingdom had come. The promised day of the Lord was ushered in." ${ }^{3}$

${ }^{1} \mathrm{C}$. S. Mann, The Message Delivered (New York: Morehouse Barlow, 1973), 18.

${ }^{2} \mathrm{C}$. H. Dodd, Apostolic Preaching and Its Developments (New York: Harper \& Brothers, 1949), 21-24.

${ }^{3}$ Dewitte T. Holland, The Preaching Tradition (Nashville, TN: Abingdon, 1980), 18. 
2. This fulfillment has taken place in the person of Jesus Christ (Acts 2:36).

3. Jesus has risen and has been exalted at the right hand of God as Prince and Savior (Ps 110:1; Acts $5: 31)$. "He is 'the stone you builders rejected, which has become the capstone'" (Acts $4: 11$, citing Ps 118:22).

4. The Holy spirit bestowed is "the sign of Christ's present power and glory." "Exalted to the right hand of God, he has received from the Father the promised Holy spirit and has poured out what you now see and hear" (Acts 2:33).

5. The Messianic Age will shortly reach its consummation in the return of Jesus. To the Roman centurion it is expressed in another way: that God appointed Jesus "as judge of the living and the dead" (Acts 10:42).

6. It closes with "an appeal for repentance, the offer of forgiveness and of the Holy spirit, and the promise of 'salvation'"1 (Acts 2:38-40, 3:19-23, 4:12, 5:31).

This concern continues through Peter's other recorded sermons. About this, C. H. Dodd asserts: The first four speeches of Peter cover substantially the same ground. The phraseology and the order of presentation vary slightly but there is no essential advance from one another. They supplement one another and taken together, they afford a comprehensive view of the content of the early kerygma. ${ }^{2}$

\footnotetext{
${ }^{1}$ Dodd, 23.

${ }^{2}$ Ibid. , 21.
} 
In summary, Peter's sermons included these elements:

1. The scriptures

2. The exegesis and interpretation of the main passages (Acts $2: 17-21$ )

3. Persuasive explanations (Acts 2:22-35)

4. Christo-centric messages

5. Illustration (Acts 2:25-34)

6. Application to people's present needs (Acts $2: 36-40)$

\section{Paul's Preaching}

Raymond Bailey went so far as to say that the portrayal of Peter and Paul in the book of Acts by Luke is "intended to show what and how to preach." ${ }^{1}$ Bailey goes on to say that "Paul was unquestionably the major interpreter of the implications of the incarnation and subsequent death and resurrection of Jesus the Christ." 2 That is, in Paul's preaching special emphasis was given to Jesus' death, burial, and resurrection with explaining the scriptures:

Now, brothers, I want to remind you of the gospel I preached to you, which you received and on which you have taken your stand. By this gospel you are saved, if you hold firmly to the word I preached to you. . . For what I received I passed on to you as of first importance: that Christ died for our sins according to the scriptures, that he was buried, that he was raised on the third day according to the Scriptures. (1 Cor 15:1-4, emphasis supplied)

\footnotetext{
${ }^{1}$ Raymond Bailey, Paul the Preacher (Nashville, TN: Broadman, 1991), 16 .

${ }^{2}$ Ibid. 13 .
} 
Paul's preaching at Athens (Acts 17) shows a similar structure. In this, the resurrection played an indispensable part. ${ }^{1}$ In preaching to Jews, Paul used old Testament quotations in a way not possible among Gentiles. At Thessalonica "as his custom was, Paul went into the synagogue, and on three Sabbath days he reasoned with them from the scriptures, explaining" (Acts 17:2-3, emphasis supplied). Possibly Paul's expository preaching motivated the Bereans to receive the message with great eagerness and to examine "the scriptures every day to see if what Paul said was true" (Acts $17: 11$ ).

In Rome, when the Jews "had appointed a day for him, they came to him at his lodging in great numbers. And he expounded the matter to them from morning till evening, testifying to the kingdom of God and trying to convince them about Jesus" from the Scriptures (Acts 28:23, RSV, emphasis supplied). Paul was an experienced preacher, however. He could have preached topical sermons. However, he expounded the kingdom of God from the scriptures. Thus his gospel reached hearts "not simply with words, but also with power,

${ }^{1}$ Frank Kamphaus asserts: "The resurrection of Jesus-this is what Paul is saying-is the basis and at the same time the medium of the Christian faith. By it the preaching of the Christian message stands or falls. This preaching lives because Christ lives and is alive in it. Hence it is that the witness to the resurrection of Jesus has become right from the outset the heart and center of the Christian kerygma." Frank Kamphaus, The Gospel for Preachers and Teachers (London: Sheed and Ward, 1974), 11. 
with the Holy Spirit and with deep conviction" (1 Thess 1:5), because the word of God is life and power.

What Paul preached at the synagogue of Pisidian Antioch is expecially appropriate for an analysis of the expository nature of his preaching. ${ }^{1}$ Notice the basic elements:

1. Jesus' historical frame of reference with which his audience was familiar (Acts 13:17-25)

2. Scriptural, historical, and logical explanations of Jesus as the Messiah of the Jews and Savior of all mankind (vss. 26-37)

3. Application of these truths to the audience (vss. 38,39 )

4. A solemn warning and appeal to his hearers (vss. $40-41)$

In summary, Paul's preaching was based on:

1. The Scriptures ("He reasoned with them from the Scriptures" [Acts $17: 2]$.)

2. Exegetical, historical exposition or explanation ("Explaining and proving that the Christ had to suffer and rise from the dead" [Acts 17:3].)

3. Christo-centric message

4. Application.

${ }^{1}$ Araujo, 37. 
THE DEVELOPMENT OF THE ADVENTIST CHURCH AMONG OTHER RELIGIONS IN KOREA

Shamanism ${ }^{1}$ has been the largest religious influence on Koreans for about four thousand years. It has had an impact on most aspects of their lives from birth to death. When they were sick, they went to a shaman. When they were in distress, when they could not have a baby, even when they had to decide the place of a tomb, they went to a shaman.

Meanwhile, Buddhism came into this land in 372

C.E. ${ }^{2}$ and began to spread rapidly. For hundreds of years Buddhism was the nation's religion supported by the

${ }^{1}$ Shamanism is a primitive religion whose strong roots are nature-worship or a polytheism or polydemonism with a supreme god over all. Shaman's main functions are healing and divination. See Encyclopedia of Religion and Ethics, 1921 ed., s.V. "Shamanism." Shamanism can also be defined as "techniques of ecstasy" to participate directly in the spiritual dimensions of reality, as healer, diviner, clairvoyant, and psychopomp (escort of the soul of the deceased to the domain of the dead). See S. D. Gill, "Shamanism" The Perennial Dictionary of World Religions, $(1989), 674$.

${ }^{2}$ Robert Evans Buswell, Jr., "Buddhism in Korea" The Encyclopedia of Religion (1987), $2: 421$. 
government. As of 1989, 8,059,000 people of the Republic of Korea were regarded as Buddhists. ${ }^{1}$

Then, the Lee Dynasty accepted Confucianism as the official religious value of the nation in 1392 . If a baby was of noble birth, it was in the upper class until it died. On the other hand, if a baby was of low birth, it was in the lower class until it died, regardless of its personal ability. For hundréds of years Confucianiam shaped Korean minds and hearts.

When missionaries brought the gospel to this land in the second half of the nineteenth century, however, things changed. The number of Christians began to increase.

Meanwhile, in recent history, the Korean war broke out in 1950. It turned Koreans' social and religious values upside down. Everybody had to begin anew with empty hands in the land destroyed through war. The traditional social system was broken which otherwise could have been a great hindrance to the new religion of Christianity. Most people, however, were better disposed to receive a new value system. Christianity, consequently, spread rapidly. Today about more than one third of the population of the nation are Christians. Almost every small village in the countryside has at least one church. The largest Christian denomination

\footnotetext{
${ }^{1}$ The Europa World Year Book (London: Europa Publications, 1993), 2:1693.
} 
in Korea is the Presbyterian Church followed by the Methodist Church.

In 1904 two Koreans immigrated to Hawaii. The ship harbored in Kobe, Japan. While they were walking along a street, they saw a church with a long denominational name, Seventh-day Adventist. They wanted to know the meaning of the name. When they entered the church, they were guided to study the Bible. In June of that year these two Koreans were baptized at a waterfall. They decided to cancel their plan for immigration in order to spread the gospel to Korea. This was the beginning of the Seventh-day Adventist Church in Korea. Missionaries from the United States of America further developed the progress of the Adventist Church in Korea.

As of January 1, 1996, the Korean Union Conference has five local conferences, 613 churches, 891 congregations, 130,028 church members, and 649 pastors. It operates ten elementary schools, eight junior high schools, seven high schools, two junior colleges, and one university, with 11,669 students and 449 teachers. It runs two general hospitals, and one dental hospital, with 176 medical doctors, 416 nurses, and 706 beds. It also manages one NEWSTART training center, one vocational school, one cemetery, four food factories, one publishing house, and nineteen language institutes with 15,000 students every month. 
72

The Seventh-day Adventist Church is vigorously growing and the prospect in the future is very bright. 
CHAPTER VI

\section{AN ANALYTICAL STUDY OF ADVENTIST PREACHING IN THE REPUBLIC OF KOREA}

In this chapter a matrix for classifying and analyzing sermons is shown, synopsis and analysis of fourteen Adventist sermons in Korea are made, and observations and conclusions are undertaken.

\section{Classifying and Analyzing Sermons: A Matrix}

In chapters 2, 3, and 4 literature was reviewed on the theology of preaching, the nature of expository preaching, and the need for expository preaching. The results of that study yielded criteria for determining whether or not a sermon is an expository sermon. These criteria are now used for the analysis and evaluation of the fourteen sermons. Each of the fourteen sermons is evaluated by the following questions:

1. Does it have a leading biblical text?

2. Is the text analyzed with adequate exegesis?

3. Is the passage interpreted and explained and are persuasive skills used to get the congregation to respond in some specific way? 
4. Is the sermon Christ-centered?

5. Is the sermon illustrated?

6. Is the sermonic theme clearly applied to the people's needs?

The matrix and the results of the evaluation of the sermons are in the section "Observations/Conclusions."

\section{Synopsis and Analysis of Fourteen \\ Sermons in Korea}

Applying the criteria established in chapter 3, this section studies and evaluates fourteen sermons recently preached by seven pastors of the Korean Union Conference. The sermons were preached in Korean, but an English synopsis of each message has been written. Included is a short description of each preacher. The cassette tapes of the sermons are on file with the dissertation in the office of the Doctor of Ministry program of Andrews University, Berrien Springs, Michigan.

Appreciation must be expressed to these preachers who have submitted their sermons for the present study. I worked with these men as a coworker, which gave me personal knowledge of them. They are sincere and dedicated pastors.

$$
\text { Sermon Number } 1
$$

\section{Background}

The preacher is an ordained pastor and a graduate from Sahmyook University with a Bachelor of Theology degree. 
He has worked as a senior pastor in various churches of the West Central Korean Conference for many years.

This sermon was preached during the second Sabbath worship service of a church, on the first sabbath of July, 1995, in one of the stewardship revival weekend meetings.

\section{Synopsis}

The sermon title was "Those who Ate the Fruit of the Tree of the Knowledge of Good and Evil." The preaching passage was Luke 12:13-15.

A man's Iife does not consist in the abundance of his possessions. A few days ago the sampoong department store collapsed. Many people died. One of the main reasons for this terrible tragedy proved to be the owner's greed. He violated the law of construction in many ways. When the building began to crack, he did not order the building to be closed. Though he tried to fix up the crack, he hid the problem so that people would continue to enter and buy things without fear. He regarded money as more.important than people's lives. As we know, life is more important than money. After the tragedy he could not adequately compensate for the lost lives. Only Jesus can give life (1 John $5: 11-12$ ).

Before Adam and Eve ate from the tree of the knowledge of good and evil, they had a living relationship with God. But when they ate of it, the relation was broken. They lost their lives. The fruit of the tree of the 
knowledge of good and evil did not have poison to kill them. There was no radical difference between that tree and others, except that God had forbidden that fruit. Likewise, one who refuses the word of God dies (John 12:4748). It is the word of God that will condemn one who rejects it. One is supposed to use all one's resources in following God's will. But Lucifer wanted to make use of his God-given resources according to his own will. He put himself in the place of God. As the result, he fell and faces death. Sin's nature is to attempt to be equal to God. The secret power of lawlessness is to exalt oneself to be equal to God (2 Thess 2:3-7). On the other hand, the mystery of godliness is that God was willing to empty Himself and become man. Christ humbled Himself and "became obedient to death-even death on a cross" (Phil 2:8). "Beyond all question, the mystery of godliness is great: He appeared in a body" (I $\operatorname{Tim} 3: 16)$. This is the mystery of godliness! The spirit of godiiness is to empty oneself to save humanity. The spirit of sin is to attempt to be equal to God.

Don't try to get hegemony in your homes and church. The wife should obey her husband, and the husband should love his wife (Eph 5:22-28). The spirit of obedience will enable you to do so. Humble yourself and be willing to be in harmony with one another in your church. 
God said, "You are free to eat from any tree in the garden" (Gen 2:16). Are all these trees Adam's or God's? They're God's. They came from God. Because God gives, one enjoys blessings and happiness. It is God who gives. Because it is safety and blessing for humanity to remember this fact, God forbade Adam and Eve to eat the tree of the knowledge of good and evil. To obey the word is to recognize God's ownership.

If a tenant farmer gives rent to the owner, he recognizes the owner's ownership. If he doesn't, he doesn't recognize it. Offering to God one tenth of one's income is recognizing God's ownership. To eat or not from the tree of the knowledge of good and evil is the test of obedience. So it is with tithe.

\section{Analysis}

The preacher seemed to try to talk about stewardship. The introductory illustration about sampoong department store was used to describe the tragedy of man's selfishness. The whole country was clamoring about the obnoxious greed of the owner who attempted to earn money at the expense of people's lives. The story of the tree of the knowledge of good and evil is working as the leading illustration.

The contrast between the secret power of lawlessness and the mystery of godliness is excellent. Christ is presented as the example to empty Himself to obedience, 
which is the key issue of stewardship. The last

illustration fits well to clarify the message and helps the application to be relevant.

However, although Luke $12: 15$ is the preaching passage, little exegesis and contextual study of it are observed. Moreover, about the half of the sermon was concerned with the story of Gen 2 and 3 , as the title of the sermon, "Those who Ate the Fruit of the Tree of Knowledge of Good and Evil," shows. It appears that the preacher tried to talk about stewardship; however, the preaching passage is talking about greed! It is a topical sermon.

Summarizing the Analysis

1. The message is not controlled by the leading text.

2. The exegesis and contextual study of Luke 12:15 were not undertaken.

3. The explanation seems to be disjointed and needs more clarity.

4. The sermon has some Christ-centered factor.

5. The sermon needs more fitness of illustration (for example, the husband and wife illustration).

6. The sermon needs more sharpness for application.

7. It is not an expository sermon. 
Sermon Number 2

\section{Background}

The church where this sermon was preached is the largest in this pastor's district. This sermon was preached on Sabbath, November 11, 1995, which was the last day of an evangelistic campaign. On that Sabbath afternoon nine persons were baptized.

\section{Synopsis}

The sermon title was "Belongingness and Destiny." The preaching passage was Josh 24:14-18.

Humanity has the following desires: (1) the desire to live, (2) the desire to eat, and (3) sexual desire. The strongest of these desires is said to be the desire to live.

God wants us to Iive. As the standard of living improves today, people exercise and seek good medicine. The Bible shows us the way to live forever. The fourth desire is that of security. The fifth is for belongingness. Today I'd like to speak of belongingness.

Belongingness often decides people's destiny. The dictator of North Korea chose the old Soviet Union. The people of North Korea under his dictatorship are suffering from dire hunger. However, the people of South Korea, who chose democracy and the United States of America, live in plenty. Belongingness decides destiny.

In the urgent situation of Korea in 1979, the generals and officers who chose General Du Hwan Chun, the 
head of a coup d'état, are now in shame. On the other hand, General Tae Wan Chang, who chose to be faithful to the government no matter what happens, has become a hero. He is respected as a true soldier. Belongingness decides destiny. Rev 12:7-9: The angels who chose Lucifer became demons. However, the angels who chose Christ are serving in the heavenly glory. Joshua said, "Choose for yourselves this day whom you will serve" (Josh 24:15).

John 8:43-44: Who belongs to the devil? It is the one who does not listen to the Word of God; those who have evil desires; liars-those who do not speak the truth; murderers; those who reject Christ and do not believe in Him-these belong to the devil. "He who is not with me is against me" (Matt 12:30). "He who belongs to God hears what God says" (John 8:47). "If you hold to my teaching, you are really my disciples" (John $8: 31$ ).

Elder Pil Won woo preached in an evangelistic campaign in Yangyang in 1962 when I was a second-year student of Yangyang High School. The campaign continued for three weeks, but I could attend the meetings only the last several days. I accepted as the word of God the prophecies of the books of Daniel and Revelation, the Sabbath truth, and the counsels on diet and food. I was baptized then. Not long after I became an Adventist, one day as I was on the way home from school I watched a shamanistic ritual. The shaman, absorbed in her performance, suddenly stopped 
the exorcism and glared at me, with a knife in her hand. Her exorcism might be hindered because I belonged to Christ. So I calmly left that place.

A person who accepts the Word of God and is baptized belongs to God immediately, and becomes a child of God.

\section{Analysis}

The theme "belongingness decides destiny" was explained and presented clearly. The preacher started his sermon with people's general desires. Then he selected one of them, the desire of belongingness.

The illustrations of the contrasts between North Korea and South Korea and between the officers who chose the coup d'état and those who chose to be faithful to the government in 1979 were timely because the terrible food situation of North Korea and the trials against the officers who chose the coup d'état leader are hot issues in Korea now.

Then the preacher led the congregation to the biblical comparison between the angels who chose Lucifer and those who chose Christ. Then he led his congregation to the passages of John 8, where the people of the devil and the disciples of Christ are contrasted.

The last illustration is good because he emphasized that a person who accepts the word of God belongs to God immediately. Then he concludes that those who accept the Word of God belong to Christ because they profess their 
faith before the church by being baptized. Now their destiny is changed. They have become the children of God. The sermon is simple and clear. It is Christcentered. The application is good. However, it seems that the preaching passage, Josh 24:14-18, is not analyzed historically and contextually or theologically. There is little exegesis there. It is a topical sermon which is not really focused on the advertised preaching passage.

\section{Summarizing the Analysis}

1. The message is not controlled by the leading text.

2. The exegesis and contextual study of the preaching passage were not undertaken.

3. The explanation is clear.

4. The sermon is Christ-centered.

5. The sermon is well illustrated.

6. The message is well applied.

7. It is not an expository sermon.

Sermon Number 3

\section{Background}

The preacher is an ordained pastor. This sermon was preached in a large church during its year-end prayer week.

\section{Synopsis}

The sermon title was "Come, Let Us Go Up to Bethel." The preaching passage was Gen 35:1-7. 
Jacob and his household camped within sight of the city of Shechem in Canaan (Gen 33:18). One day Dinah, Jacob's daughter, "went out to visit the women of the land" (Gen 34:1). When Shechem, son of Hamor, "the ruler of that area, saw her, he took her and violated her" (Gen 34:2). And Hamor and shechem asked Jacob and his household to give Dinah to them for marriage. Jacob's sons asked them to circumcise all their males as a condition. Thus every male in the city was circumcised. Three days later, while all of them were still in pain, two of Jacob's sons, Simeon and Levi, Dinah's brothers, took their swords and attacked the unsuspecting city, killing every male. Jacob felt heavyhearted and afraid. Then God said to Jacob, "Go up to Bethel and settle there, and build an altar there to God, who appeared to you when you were fleeing from your brother Esau" (Gen 35:1).

The fact that girls are violated happens today also. Also those who have money or power do injustice today. It was in the city of shechem that immorality and materialism prevailed. It was a fascinating city. Modern cities are like the city of shechem. Because the world seduces us today, many even want Jesus to postpone His coming.

But the problem is not the charm and wickedness of this world. The problem is modern Dinahs in the Adventist Church today who crane their necks to see the appeal of the city of shechem. The problem is that Adventists are 
covetous of the fascination of the world. The problem is Dinahs of Adventism who are broken by Shechems of the world. We all are Dinahs. What should you do at this crisis?

First, you should go to Bethel. Jacob said, "Come, let us go up to Bethel, where I will build an altar to God, who answered me in the day of my distress and who has been with me wherever I have gone" (Gen 35:3). It was at Bethel that God appeared to Jacob, who feared. It was at Bethel that God said, "I am with you and will watch over you wherever you go" (Gen 28:15). It was at Bethel that God gave Jacob, a sinner, hope and courage.

They took up the tents and started for Bethel. I think of the journey of Adventists for heaven. We should start for Bethel, departing from Shechem. This sinful world is not our home. Pluck out the stake driven deep into the world.

There was a dancer named Isadora Duncan. She was famous for dancing. She met a rich man and enjoyed happiness. One day she drove an open car along a lane with her husband. She was ecstatic, with a long muffler around her neck. But all of a sudden the muffler became caught in a wheel of the car. It caused her death. How long a muffler are you flying? Beware of the cars of shechem. Cut off your muffler.

Second, you should go up to Bethel with your family (Gen 35:2). Where is your husband? Isn't he buying or 
selling in shechem in the name of support for his family? Where is your wife? Isn't she under the influence of pleasure to buy the things in shechem? Where is your son? Isn't he angling after girls in shechem? Where is your daughter? Isn't she following the girls in shechem to meet their standards? Where are you? Aren't you having fun with the people of shechem? Gather your family and go up to Bethel with them.

Third, you should get rid of the foreign gods you have with you (Gen 35:2). There were three representative foreign gods to the ancient Israelites: Mammon, which represents money and riches, Molech, which represents murder and violence, and Baal, which represents lewdness and immorality.

Greed is idolatry (Col $3: 5)$. It does not necessarily represent only the love of money. It includes the love of honor. It includes the love of power. It includes the love of beauty. So some women have plastic surgery on their noses in order to make them better, though they have no problem with their noses. People covet pleasure. Is money bad? No. It is good. Is honor bad? No. It is good. But coveting means desiring beyond discretion. "Each one is tempted when, by his own evil desire, he is dragged away and enticed. Then, after desire has conceived, it gives birth to sin; and sin, when it is fully grown, gives birth to death" (Jas 1:14-15). "Get rid 
of the foreign gods you have with you" (Gen 35:2). You may say, "I have no greed," or "It's not me." If you have something which you love more than God, that is greed. If you have something without which you feel afraid except God, that is greed. Your bank deposit can be your idol. Your children can be your idol. You must get rid of foreign gods.

Fourth, you should purify yourself (Gen 35:2). Jesus said, "First clean the inside" (Matt 24:26). To purify themselves, many people repeat repentance and try to shed tears with difficulty. But they do not repent of the sins as they must. How can you purify yourself? It is simple. Jesus cleansed the Jerusalem temple (John 2:13-17). The presence of Jesus brings purification. How can you purify yourself? When you invite Jesus into your heart, your heart is purified.

Many Adventists say well, "Amen. Come, Lord Jesus" (Rev 22:20). But only those who open the door of their hearts can say that day, "Come, Lord Jesus." Let us invite Jesus into our hearts now.

Fifth, you should change your clothes (Gen 35:2). "They gave Jacob. . . the rings in their ears" (Gen 35:2). To give the rings in one's ears is to change one's clothes. To give the rings includes more than to give the rings in one's ears. It is to cast away one's dressing up and formalism. To try to show that one is better than others is 
prompted by the spirit to take an earring. It includes the spirit to try to show that one prays more than others. It includes the spirit to try to show that one is godlier than others. Your beauty "should be that of your inner self, the unfading beauty of a gentle and quiet spirit, which is of great worth in God's sight" (I Pet $3: 4$ ). "God is spirit, and his worshippers must worship in spirit and in truth" (John $4: 24$ ). If you attend prayer meeting and begin to look down on or criticize an elder who does not attend the meeting, you take an earring. Let us wash our robes and make them white in the blood of the Lamb (Rev 7:14).

"They set out, and the terror of God fell upon the towns all around them" (Gen 35:5). The problem is not that this world is decaying. The problem is that we love this world. Reformation brings power. Why do Adventists have a form of godliness, not its power? Because there is no reformation. Come, let us go up to Bethel.

A big, beautiful swan arrived at a lake. It enjoyed eating many fish. Then it wanted to fly. But the sun was sinking. It chose to sleep that night in the lake. Unfortunately it was very cold that night. The lake was frozen into ice. Next morning the swan could not fly because its legs were stuck on the ice. Then, a little sea gull flew near and saw what was happening. The seagull made an effort to catch a fish and gave it to the swan. It kept on doing that. Meanwhile the sun rose and the ice melted. 
The swan then flew freely across the blue sky. My swans, I've spoken to you with the mind of a little sea-gull. This sermon may be just a few fish. But I entreat you to fly across the blue sky for your home. This world is not your home. Let us throw away the love of Shechem, this world. Come, let us go up to Bethel.

\section{Analysis}

The historical background and the context are adequately explained. The preacher said what the text said and what it means today for the congregation. He developed his sermon directly from the passage, and the flow of the contents is controlled by the text. The sermon is beautifully Christ-centered; Christ is exalted and presented as the One who purifies the soul temple. The illustrations are proper. The last illustration is powerful. The application in each division very well fits the congregation.

The preacher said, however, "But the problem is not the charm and wickedness of this world. The problem is modern Dinahs in the Adventist Church today who crane their necks to see the appeal of the city of shechem. . . . The problem is Dinahs of Adventism who are broken by Shechems of the world." The preacher blamed the victims instead of sin. The preacher should have blamed sin instead of the victims. Nevertheless it is a good expository sermon. 
Summarizing the Analysis

1. The message is controlled by the leading text.

2. The exegesis and contextual study of the leading text were well undertaken.

3. The explanation is persuasive.

4. The sermon is Christ-centered.

5. The sermon is well illustrated.

6. The application is fit.

7. It is an expository sermon.

\section{Sermon Number 4}

\section{Background}

This sermon was preached in a Sabbath worship at the pastor's church. Recently this church rejoiced to welcome many new baptized members.

\section{Synopsis}

The sermon title was "Do the Works of Abraham." The preaching passage was John 8:39-41.

Gen 18:17; Amos 3:7: Today unbelief is prevailing everywhere. Even Christians are influenced by this sin. In this age, God wants to see the righteous like Abraham (John $8: 39-41$ ). When Jesus said to the Jews, "You will know the truth, and the truth will set you free" (John 8:32), they answered Jesus, "We are Abraham's descendants and have never been slaves of anyone" (John 8:33). Then Jesus said to them, "If you were Abraham's children, then you would do the 
things Abraham did" (John 8:38). Let us see who are in this day Abraham's true descendants.

Abraham is the ancestor of believers, not of the Jews in a true sense (Matt $3: 8-9$ ). Jesus said to the Jews, "You belong to your father, the devil, and you want to carry out your father's desire" (John 8:44). Whom should we resemble? The devil or Abraham? The devil does not hold "to the truth, for there is no truth in him. When he lies, he speaks his native language, for he is a liar and the father of Iies" (John 8:44). Abraham's descendants should do the things Abraham did. What are the things Abraham did? (Rom $4: 18-24$ ).

First, "he did not waver through unbelief regarding the promise of God but was strengthened in his faith" (Rom 4:20), "although he faced the fact that his body was as good as dead-since he was about a hundred years old-and that Sarah's womb was also dead" (Rom 4:19). Let us not doubt God's promise. It is not difficult to keep one's faith when things are all right. But one should believe in God's promise even when things are not all right.

Abraham "believed-the God who gives life to the dead and calls things that are not as though they were" (Rom 4:17). When you face great difficulties and trials, if you believe in God, God can resurrect your situation. God is the God who "calls things that are not as though they were." 
Second, he "gave glory to God" (Rom $4: 20$ ). It is not easy to give glory to God in afflictions and trials. But this is the Iife Christians should live.

Third, he was "fully persuaded that God had power to do what he had promised" (Rom 4:21). "He believed-the God who gives life to the dead and calls things that are not as though they were" (Rom $4: 17$ ).

These days are difficult. God wants to see Christians who do the things Abraham did. Do you have disease? Are you in distress? Are you on the brow of a cliff in things? Do you have trials? God can give life to the dead. As Abraham's descendants let us live with true faith in God as Abraham did.

\section{Analysis}

From John 8:39-41 the preacher tried to tell why the congregation should do the things Abraham did, and from Rom 4:17-25 he made efforts to speak on how the congregation could do them. Rom 4:17-25 was explained with three divisions in regard to the characteristics of Abraham's Eaith.

The context and history of the texts were considered adequately, and the passages were well explained with proper illustrations. The sermon was practical. The message is very applicable to the audience including the newly baptized members. 
However, the logic of three divisions from Rom 4:1721 was not distinguished clearly. The three divisions were similar in theme. Some illustrations of the second division seemed not to fit. Furthermore, though the leading text is John 8:39-41, the divisions of the sermon came from Rom $4: 17-21$. The sermon does not focus on and explain a single clear passage. In addition, it is not easy to say that this sermon is Christ-centered.

\section{Summarizing the Analysis}

1. The message is not controlled by a single clear passage.

2. The exegesis of the preaching passage was not well undertaken.

3. The logic of the three divisions from Rom 4:1721 was not distinguished clearly.

4. It is not easy to say that this sermon is Christ-centered.

5. Some illustrations of the second division seemed not to fit.

6. The application is good.

7. It is not an expository sermon.

\section{Sermon Number 5}

\section{Background}

The preacher is in his thirties and an ordained pastor. He graduated from the graduate school of sahmyook 
University with an M.A. in religion, and has worked for about ten years as a church pastor in the West Central Korean Conference.

\section{Synopsis}

The sermon title was "Blow the Trumpet in Zion." The preaching passage was Luke $3: 3-6$.

The prophet Jeremiah said, "Let us examine our ways and test them, and let us return to the LORD" (Lam 3:40). The prophet Joel said, "Rend your heart and not your garments. Return to the LORD your God" (Joel 2:13). When we return to the Lold, we shall receive the Latter Rain (Joel 2:23). God said, "Blow the trumpet in Zion; sound the alarm on my holy hill. Let all who live in the land tremble, for the day of the LORD is coming" (Joel 2:1). Why do people laugh at us instead of trembling, although we have blown the trumpet for so long a time?

Sins are prevailing everywhere more and more. Ellen G. White said in the Testimonies for the Church, vol. 9, p. 19 :

In a special sense Seventh-day Adventists have been set in the world as watchmen and light bearers. To them has been entrusted the last warning for a perishing world. On them is shining wonderful light from the word of God. They have been given a work of the most solemn import-the proclamation of the first, second, and third angels' messages. There is no other work of so great importance. They are to allow nothing else to absorb their attention.

She also said in the Gospel Workers, p. 251: 
We talk about the first angel's message and the second angel's message, and we think we have some understanding of the third angel's message. But as long as we are content with a limited knowledge, we shall be disqualified to obtain clearer views of truth.

Therefore we shall study more about the three angels' messages today.

The three angels' messages are often called Elijah's messages. John the Baptist was called God's messenger to prepare people for the first advent of Christ. His message is written in Luke 3:4-6. Likewise the Seventh-day Adventists are called God's messengers to prepare people in the world for the second advent of Christ. Their messages are written in Rev 14:6-12. And we can see that the message of John the Baptist in Luke 3:4-6 is quoted from Isa 40:311. The message of Isa 40:3-5 has some similarities to the three angels' messages of Rev 14:6-12.

\section{In Isa 40:3-11 three voices come like three} messages: "A voice of one calling" in vs 3, "a voice" in vs 6, and "you who bring good tidings to zion" in vs 9 . Also "the eternal gospel" of Rev 14:6 can be compared with "good tidings" of Isa 40:9. But how are these two passages of Rev 14:6-12 and Isa 40:3-11 felt differently? It is because the people who hear these messages are different from each other.

The first angel's message of Rev $14: 7$ is to "Fear God and give him glory because the hour of his judgment has 
come." In Isa 40:3-5, the message is to prepare the advent of God.

I began to believe in God when I was a sophomore at Choongang University. Studying the Bible, I began to understand that the call to keep the Sabbath is the call to meet God. But because in my elementary school years I fell into the habit of smoking, I couldn't stop smoking. I tried many things to be able to quit smoking, but I couldn't. One day I desperately prayed to God, saying "God, show me your creating power. As you know, I am addicted to smoking. Please help me stop it." Amazingly enough, I found myself not even thinking of cigarettes for a week! I was so amazed and overwhelmed that I couldn't but admit God's creating power. I accepted God as my Creator. I also prayed to God for the cessation of drinking alcohol. God helped me quit drinking liquor. I met God the Creator. Then I dedicated all my being to God.

When a person meets God, one's "valley shall be raised up," and one's "mountain and hill made low" (Isa $40: 4)$. God saves one from the valley of disappointment of sin and bad habits. God also flattens one's mountain of pride and self-exaltation. The first angel's message is the call to meet God. This is the message of justification. The second angel's message is "Fallen! Fallen is Babylon the Great." As Babylon the Great is fallen, "all men are like grass, and all their glory is like the flowers 
of the field. The grass withers and the flowers fall" (Isa $40: 6-7)$. All the efforts to get righteousness to be saved by human efforts are fallen. Because Babylon is fallen, people must come out of Babylon. Isn't the tower of the habits of Babylon high? Come out of the tower of the habits of Babylon. Jesus gives the power to do so. Behold Jesus, and you will resemble Him. This is sanctification.

A sculptor carved a calf of wood. It was like a real calf. A student asked how he could do so. The sculptor said, "Cut off the parts of the wood which do not resemble a real calf!" Let's pray, "Lord, please cut off the self which does not resemble Jesus."

Monkey hunters have a secret for hunting monkeys. A hunter puts a bean in a long, narrow, transparent, heavy bottle. And he places the bottle at a place where monkeys often pass by. Once a monkey sees the bean, which it likes to eat, it puts its hand into the bottle and grasps the bean with exultation. When it tries to pull its hand out of the bottle, it is not easy for it to do so. If it gives up the bean, it can pull its hand out of the bottle. But it will not give up the bean. Then the monkey hunter comes. The monkey can't run away because the bottle is heavy. The hunter does not have to hurry about catching the monkey. He walks slowly. Let us release our hold of worldly things, which can be the snares of Satan. 
The third angel's message of accepting the seal of God is the message of accepting the shepherd. He tends His flock, "gathers the lambs in his arms and carries them close to his heart"; and "gently leads those that have young" (Isa $40: 9-11)$

One day a man looked back at his past. He saw two persons' footprints on the sand. But when he suffered from hardships and adversities, he could see only one person's footprints there. He said to Jesus, "Lord, when I was suffering hardships and difficulties, when I needed You most, why didn't you walk with me?" Jesus said, "My child, when you were suffering from hardships and adversities, I carried you close to my heart." Let us accept this shepherd as our shepherd. This is the third angel's message. It is glorification.

\section{Analysis}

This sermon tried to compare the three angels' messages with the messages of Isa 40:3-11, and to tell what the three angels' messages really mean to the congregation today. This sermon hints that the three angels' messages are neither the mark of the beast nor the doctrine of the Sabbath. It says that the three angels' messages are the call to meet the Creator who can recreate our bodies, minds, and hearts, to come out of the habit of self-worship, to accept the Shepherd of love. This sermon consists of three divisions from the texts of Rev 14:6-12 and Isa 40:3-11. 
In the first division the preacher's personal experience became a compelling illustration to meet God who can create a new mind and heart. In the second division, a sculptor's word and monkey hunter's secret were touching illustrations. In the third division, the story of footprints was an impressive illustration in relation to the Shepherd.

The message was Christ-centered, and the application was clear and moving. However, the preacher tried to explain that the first angel's message is justification, the second angel's message, sanctification, and the third angel's message, glorification. Whether that sermonic idea is faithful to the text or approved by Adventist scholars is questionable. The preacher tried to find the same characteristics of the three angels' messages in Isa 40:311. He offers insufficient support for this conclusion. In addition, though the leading text is Luke 3:3-6, little exegesis and contextual study of it were undertaken. The sermon consists of bits and pieces of several passages rather than a thorough explanation of a single unified text. It is a topical sermon, not exegetical.

\section{Summarizing the Analysis}

1. The message is not controlled by the leading text.

2. The exegesis of a single unified text was not undertaken. 
3. Insuffient support for the explanation was offered.

4. The message is Christ-centered.

5. The sermon is well illustrated.

6. The application is good.

7. It is not an expository sermon.

\section{Sermon Number 6}

\section{Synopsis}

The sermon title was "The Holy spirit like Fire and the Principles of Healing." There was no preaching passage.

The Holy Spirit has some characteristics like fire. What special features does fire have?

First, fire consumes things. "Our God is a consuming fire" (Heb 12:29). The Holy spirit extinguishes sins. He consumes all sins such as pride, selfishness, lust. When I was young, one of my friends wanted to play with fire. He struck a match to a corner of rice straw in the barn. He thought that he could put out the fire immediately. But suddenly the fire spread all through the rice straw in the barn. He was horrified. He hid in a place in the barn where he had often hid himself when he had played hide-and-seek with his friends. When he hid himself there, nobody could find him. The village people came. My friend's father came, too. Intuitively with a loud voice he called his son and kept calling him. No answer. He repeatedly called to his son, "Ojang, come out." But no 
answer. He was found burned to death. If he had come out, his dad would have forgiven him.

If you sin, don't try to hide from God. Come forward to our heavenly Father. He will forgive you and accept you.

Second, fire regenerates. "No one can enter the kingdom of God unless he is born of water and the spirit" (John $3: 5$ ). If you want to change an iron tool, what must you do? You must throw it into fire and.remake it. Likewise, the Holy spirit regenerates men and women.

When I was preaching in Suwon, a lady came in. Her face was filled with weariness and disappointment. As the sermon went on, her face began to brighten. The next Sabbath she came again, and came continuously. Through talking with her, I knew that her husband had failed in his business. Her family was thrown into severe poverty. No money, no house. The husband became an alcoholic. He continued to be fired from every new job. They had three daughters who were students. The wife found a job dealing with lead in an electronic factory. The smell of lead was always on her. She was on the brink of burnout physically and mentally. Then, she accepted Jesus as her personal Savior. She began to pray that her three daughters could come to church. She was afraid that her husband would not permit it. She asked me to pray for him so that he would permit them to come to church. I suggested to her that she 
had better pray for her husband to believe in Jesus instead of praying for him to permit it. She seemed to be dismayed. Later, I learned that he was an alcoholic. Nevertheless, she accepted my suggestion. If I waited for the husband to free himself from alcohol, I thought I could never teach him the Bible. I earnestly prayed for him. Before I started for his house, I fervently prayed for the filling of the Holy spirit. To the alcoholic I witnessed for Jesus with a prayerful heart. In closing, I said to him, "Do you want to accept Jesus as your personal Savior?" I marveled to hear him say, "Amen." Like a dream, Bible studies began. He was baptized. All his family members became seventh-day Adventists. Then they moved to another city. A long time passed by. I didn't know how they were. I was afraid that they might forsake the Lord. One day I learned that they were working at seoul Adventist Hospital. Their daughters are honor students. They are the owners of an apartment. Recently I met the husband. The family's faces were aglow. Above all he and his family members are all in Jesus. The Holy Spirit regenerates men and women.

Third, fire unites. Jesus prayed that we might be one (John 17:21). Uniting iron tools requires melting them in the fire. One day a lady came to our health institute. She very much hated her husband. I saw that she got a disease because she hated him so much. I suggested to her that she should forgive him. As soon as I finished my 
words, her face became red. She said, "I will never forgive such a fellow." After that, however, she seemed to struggle with this matter. Five days later, she said to me, "Pastor, I've decided to forgive him." I said, "What a decision!" She called him from my office. The moment she heard her husband's voice, she cried, "I get angry just to hear your voice." Then she hung up with anger. With surprise I said to her, "Didn't you dial to forgive him?" With a sigh she replied, "I got angry the moment I heard his voice. I don't know why I did that. I am confused. I want to, but I can't." We can't forgive by ourselves. I explained to her that forgiveness is God's gift. Only the Holy Spirit can give us the power to forgive. Days passed by. She seemed to begin to submit herself to Jesus. Many times I saw her climb a hill to pray. One day she came and said, "Pastor, Jesus forgave me, a great sinner. So I should forgive others. Now I not only forgive him but also love him." They were reunited. The Holy spirit can unite.

Fourth, fire warms up. There are many people who want to be loved. Let's love them with the warming love of the Holy spirit. After a tiger catches a monkey, the other monkeys suffer from stress. They catch lice to calm down stress. Some monkeys do that alone. Others help each other. Which do you think would calm stress more? Those who help each other. People are supposed to live one for another. This world is full of stress. Let's love one 
another.

Fifth, fire gives power. Jeremiah said, "If I say, 'I will not mention him or speak any more in his name,' his word is in my heart like a Eire, a fire shut up in my bones. I am weary of holding it in; indeed, I cannot" (Jer 20:9). Whenever I talk about Jesus, I absorb myself in it. Enthusiasm flows out. One day I was teaching a person the Bible. The next time this person brought about fifteen people to the Bible study. I said, "What happened?" The person said, "Pastor, your voice is not the one which only one can hear. Your voice must have the appropriate congregation." The Holy spirit gives power.

Sixth, fire enlightens the path. The psalmist wrote, "Your word is a lamp to my feet and a light for my path" (Ps 119:105). One night a blind person was walking with a lamp. One said, "Because you are blind, you don't need a lamp." The blind person said, "That's right. But others need it not to bump against me." One night the blind person bumped against a person. The blind person became angry and said, "Didn't you see this lamp?" The other person said, "Your lamp has no fire. It may have run out of oil." Let's pray for the oil of the Holy spirit. He enlightens our path.

\section{Analysis}

This message is about the ministry of the Holy Spirit in regard to healing souls. The preacher tried to 
apply this sermon to the hearers' need. Christ's function is presented in the first three divisions.

The preacher employed many illustrations. Though they gave light to the points which the preacher tried to make, the major part of the sermon was not explanation but illustrations. Furthermore, this sermon has no leading text. Accordingly, no exegesis and contextual study was undertaken. This sermon is a typical topical sermon.

Summarizing the Analysis

1. The sermon has no leading text.

2. No exegesis or contextual study was undertaken.

3. The explanation is clear.

4. In some divisions Christ was presented.

5. The sermon is well illustrated.

6. The sermon is well applied.

7. It is a topical sermon, not expository.

Sermon Number 7

\section{Background}

The preacher works as the senior pastor of one of largest churches in seoul in the West Central Korean Conference. He has worked as a pastor for more than fifteen years and is in his upper forties. 


\section{Synopsis}

The sermon title was "These You Ought to Have Done, without Leaving the others Undone." The preaching passage was Matt $23: 23$.

There may be no people like the Koreans to highly regard one's appearance and to consider dressing up as important. When the Hung Sun Dae Won Kun wielded power, an aristocrat visited him to get a government post. He hemmed and cleared his throat to attract attention, being haughty. Dae Won Kun saw this man's arrogance. When Iunch was given, the man ate only a little food, saying, "My stomach is not good." Dae won Kun saw this man's hypocrisy. Thus he returned home with emptiness.

Jesus rebuked the hypocrisy of the teachers of the law and Pharisees. He reproached them seven times in Matt 23.

A young pastor talked about one of his elders to me, saying, "Pastor, I am very concerned about him." His church. is in a rented building. Whoever comes first opens the lock, memorizing the number. One day the pastor arrived at the church. The elder was waiting and said with burning anger, "Why didn't you come earlier and open the lock?" One day as the pastor was about to step into the pulpit, the elder said, "Pastor, how many homes did you visit last week?" The pastor said, "I was busy last week, elder. So I couldn't visit homes last week." The elder 
said, "Why do you want to preach without visiting souls?" Some new comers brought their children to church. The kids made noise. Nevertheless, the pastor wanted more new comers to come to church. The elder, however, one day said to the parents: "Why do you let your children make noise?" The next Sabbath, one new comer didn't come to church, being hurt.

This elder had a habit of borrowing money from new comers. The older church members knew what he was, so they did not lend money to him. But new comers did not know him. So they lent money to him. One day on his birthday, he announced, "Everybody is welcome to my birthday party." Then the new comers became concerned about him, because he borrowed money from them and then wanted to have a big birthday party.

It is not good if a person is seen as pietistic and godly in appearance, but unbalanced in life. Jesus warned against hypocrites. The Pharisees gave a tenth of their spices-mint, dill, and cummin. Mint, dill, and cummin were not ordinary income but precious and rare income. The Pharisees not only gave common tithes but also gave a tenth of special income and gifts. They gave accurate tithe. Jesus said, "But you have neglected the more important matters of the law-justice, mercy, and faithfulness." That is, although they gave accurate tithe, the relationship between them and God, the source of justice, mercy and 
faithfulness, was broken. The Pharisees fasted twice a week (Luke 18:12). But Jesus said, "Unless your righteousness surpasses that of the Pharisees and the teachers of the law, you will certainly not enter the kingdom of heaven" (Matt $5: 20)$. The better righteousness is found only in Jesus Christ.

Today some Adventists attempt to question the need of high standards in lifestyle, emphasizing the doctrine of righteousness by faith. Some Adventists think it is all right to buy on the sabbath. It is certainly correct that keeping the sabbath holy, giving tithe, and obeying the principles of health are not the basis for salvation. Those, however, who are saved by the better righteousness of Jesus Christ will certainly keep the sabbath holy, give tithe, and obey the principles of health.

"A man is justified by faith apart from observing the law" (Rom 3:28). "Do we, then, nullify the law by this faith? Not at all! Rather, we uphold the law" (Rom 3:31). Therefore Jesus said that you should practice both.

The Pharisees tried to be saved by their works. And they tried to keep God's commandments with all their might. On the other hand, we have been saved by God's abundant grace in Jesus Christ. How much more should we obey God's commandments with thanks and willingness! 
Analysis

The sermon was Christ-centered with an emphasis on the righteousness by faith in Jesus Christ. At the same time, it emphasized obedient faith in real life. A few illustrations at the beginning of the sermon were not only compelling but also showed the problems of people who were pietistic in appearance.

In the text, Jesus emphasized the more important matters of the law-justice, mercy, and faithfulness, rebuking their hypocrisy. In the sermon, however, though the preacher clearly stated, "A man is justified by faith apart from observing the law," he emphasized obeying God's commandments as one who has been saved. Therefore the emphasized points are not the same. There is internal inconsistency. The preacher could have chosen better supporting texts. It is a textual sermon, not expository.

Summarizing the Analysis

1. The message was not controlled by the leading text.

2. The exegesis and contextual study of the preaching passage were not undertaken.

3. There is internal inconsistency in explanation.

4. The sermon is Christ-centered.

5. The sermon is well illustrated.

6. The sermon is well applied.

7. It is not an expository sermon. 
Sermon Number 8

\section{Synopsis}

The sermon title was "The Ransom." The leading text was Isa 43: 1-7.

Isa 43:1 begins with "But now." It means that Isa 43 begins with the words which are opposite to the words of the end of Isa 42 . Isa 42 says that God's people became those who were blind and deaf. They were spiritually miserable.

God says, "O Jacob," "O Israel" (Isa 43:1). Jacob means "the one who grasps heel" (Gen 25:26). It has another meaning of "the one who deceives" (Gen 27:36). God changed Jacob into Israel (Gen 32:24-30). Likewise, though we are sinful, God can change us into "Israelis."

God says, "Fear not, for I have redeemed you; I have summoned you by name; you are mine" (Isa 43:1). God called Abram. Although Peter denied Jesus three times and cursed Him, God called Peter's name, saying, "Tell his disciples and Peter" (Mark 16:7). The Lord called Saul on the road to Damascus (Acts 9:4). God knows us personally and calls our names. Though we sin and err, God calls us.

God says, "When you pass through the waters, I will be with you; and when you pass through the rivers, they will not sweep over you. When you walk through the fire, you will not be burned; the flames will not set you ablaze" (Isa $43: 2$ ). When Daniel's three friends were thrown into the 
fire, Christ was with them. Whatever trials you may meet, God will be with you.

The Apostle John's disciple, Polycarp, was working as the overseer of the church in smyrna. On February 23, 155 A.D., with eleven Christians he was arrested and put under the convoy of the troops. That day was the Sabbath and he was eighty-six years old. The captain of the troops felt sympathy for the aged Polycarp and said, "old man, think of your age. If you say this word, I can release you. Say 'Caesar is my God,' and I will set you free." Polycarp said, "Because you say consider my age, I will speak. I am eighty-six years old. For eighty-six years, God has never disappointed me. Never once. How can I disappoint Him who has never disappointed me?" The captain got angry and said, "You will be the prey of a lion." Polycarp didn't lose his peace. Then the captain said, "You will be burned in fire." Then Polycarp said, "Though I die in fire, Christ will resurrect me. After that the judgment of fire will come." When people attempted to nail Polycarp's hands to wood, he said, "You don't have to do that. Because the Lord is with me, He will help me not be shaken in the fire. He will help me die in peace." He prayed in the smoke, "Lord, thank you for making me, through the spirit of the Lord, one of the martyrs. Thank you for having me participate in drinking the cup of the Lord." 
Let's give our thanks to the Lord for the promise of victory even in the flames of fire. God says, "For I am the LORD, your God, the Holy One of Israel, your Savior; I give Egypt for your ransom, Cush and Seba in your stead" (Isa $43: 3$ ). Israel was a very small nation. God says, however, that He gives Egypt, the great country, for "your ransom," Cush and seba, the rich countries, "in your stead." Think of the Exodus. God gave Pharaoh's troops in exchange for Israel. Though Abram sinned by lying that his wife was his sister, Pharaoh was punished (Gen 12:10-20). I couldn't understand why the Pharaoh had been punished, although Abram sinned. I could understand it after reading Isa 43:3. It was ransom! Though David sinned by taking a census of Israel and Judah, seventy thousand of his people died. He said to the Lord, "I am the one who has sinned and done wrong. These are but sheep. What have they done? Let your hand fall upon me and my family" (2 Sam 24:17). It was David who sinned. But it was his people who were punished. I couldn't understand the reason. But with Isa $43: 3$, my question was solved. It was ransom! God says, "Since you are precious and honored in my sight, and because I love you, I will give men in exchange for you, and people in exchange for your life" (Isa 43:4).

My father died when I was very young. I've never seen him. My uncle brought me up. When I was in junior high school, he had an accident and died. So I had no 
choice but to quit studying and do farming in the country. When I saw students passing by, I could not suppress the desire to study. I said to myself, "If my father was alive now, I could study. If my uncle was alive now, I could study." But if my father would live now, I might not be a. pastor. If my uncle lived now, I might not be an Adventist. My father and uncle may be my ransom.

Recently some people who earned money improperly were dishonored. Their deeds were made known to the world. They are our ransom. Seeing this, we can confess to God, "Lord, now I see that money and honor are not everything."

Recently, the ground under a railroad track suddenly collapsed and seventy people in the train died. They were our ransom. You may have seen one of your family members die. You may have seen one of your relatives suffer. You may have seen one of your close friends in grief. Seeing our neighbors who are suffering death and grief, can we say like David, "God, it is we that sinned. But you struck these people?" Seeing our ransom, can we hear God's voice and respond to $\mathrm{Him}$ in repentance?

\section{Analysis}

The leading text is Isa $43: 1-7$. The grammatical, historical, and contextual exegesis and interpretation were well undertaken and clearly explained with apt illustrations. The message was Christ-centered with healing influence. It is to hear God's calling to repentance 


\section{3}

through our ransom's death and sufferings that the preacher tried to speak. Divine love is felt through this sermon, and the application was delicate and powerful.

Polycarp's story was told in regard to the passage, "The flames will not set you ablaze." He was, however, burned with the flames and died. It seems that the explanation that the flames have not physical but spiritual meaning was lacking.

The preacher sang a song titled "We Are Never, Never," before he explained the meaning of "ransom" (Isa $43: 3$ ). It would have been better if he had sung the song after he explained the passage, when the congregation was moved with the love of God contained in the meaning "ransom." Nevertheless, this sermon is an effective expository sermon.

\section{Summarizing the Analysis}

1. The sermon is controlled by the leading text.

2. The exegesis and contextual study of the preaching passage were undertaken.

3. The explanation is persuasive.

4. The sermon is Christ-centered.

5. The sermon is well illustrated.

6. The sermon is well applied.

7. It is an expository sermon. 
Sermon Number 9

\section{Background}

The preacher is in his upper fifties. He has taught as a professor of theology at Korean Union College for many years, except for the period of studying in the states. He is now working as a professor of theology at sahmyook University in Seoul, Korea, with the office of an administrator. This sermon was preached at sahmyook University Church on a Sabbath.

\section{Synopsis}

The sermon title was "Let's Respond to God's Love." The preaching passage was James 1:15-18.

Though winter came last Thursday according to the calendar, the beauty, fragrance, and sweetness of autumn still remain. Seeing fallen leaves, blossomed chrysanthemums, and pears sold by the roadside, we can say, "Autumn is far advanced." A poet wrote, "Did cuckoos sing from spring to have a chrysanthemum blossom?" Sooner or later, roasted sweet potatoes will appear by the roadside. Then we will see that winter is far advanced. Fallen leaves may symbolize humans who disappear after living in this world.

Jas 1:15-18: From the sentence, "I have money" we can read people's thoughts, "I have, so I exist." But Jesus said, "What good is it for a man to gain the whole world, and yet lose or forfeit his very self?" (Luke 9:25) 
Therefore a person's value consists not in abundant possessions but in abundant existence. This is the message which God gives the former President Tae Woo Rho. It is also the message which God gives the people who criticize, and yet might attempt to earn a great amount of money in an improper way if they had a chance. We now see a scandal in which possession breaks existence. We should understand how a human being's desire makes his existence miserable.

Life is the stream of unselfish love. When one responds to love, Iife originates. Love is the essence and source of life. No love, no life. Love is the power which brings existence. At the bottom of all people's desire, there is the desire to be loved. The desire to be loved is to exist. The thing that one should do to love is to believe. How can one love without believing? Jesus said, "For God so loved the world that he gave his one and only Son, that whoever believes in him shall not perish but have eternal life" (John $3: 16$ ). Without faith love cannot be experienced. Without experiencing love, there is no life. "Whoever does not love does not know God, because God is love. This is how God showed his love among us: He sent his one and only son into the world that we might live through him. This is love: not that we loved God, but that he loved us and sent his son as an atoning sacrifice for our sins. Dear friends, since God so loved us, we also ought to love one another" (1 John 4:8-11). 
We see now why cuckoos sing from spring to have a chrysanthemum blossom. We see now why bees and butterflies eagerly fly from spring to have a pear in autumn. Why? Because of love. So it is with a pumpkin. In fact, the whole world is full of love. The result of love is life. Those who accept God's love with faith have eternal life.

You know from recent mass media that there were those who hated themselves and the world. They established a factory in which they could kill men and women. They kidnapped people, brought them to the killing factory, killed them, and burned them to destroy the evidence. The good news is that the six murderers have been born again. Mrs. Jae Myung Lee gave money for the inmates, sent them letters, and visited them. They responded to this love. The head of the gang wrote this confessing letter: "I suffer from the unbelievable fact that I did such wicked and obnoxious things. I could have done good things with my organizing and facilitating ability. Now I accept Jesus as my personal savior at the cross. The whole world is so beautiful!" He hated the world. How did this happen? The terrible murderers accepted God's love and responded to it. Why can't we do that? He changed the horrible murderers! Why can't God change us? 
Analysis

The preaching passage is Jas 1:15-18. The message is: Desire gives birth to sin and death, but love gives birth to fruit and life. God's love gives birth to eternal life. Let's respond to God's love. The preacher's Iyric introduction about autumn, fallen leaves, chrysanthemums, cuckoos, pears, longing, and love was fit for the congregation which consisted of university students. Using the sensational scandal that shocked most people in Korea, he turned his congregation from possesion-pursuing life to meaningfully living life, from desire to love. The words "desire, gives birth, death, gifts, lights, firstfruits" were key words in the text. From these words, the preacher drew existence, God's love, and life.

The message was Christ-centered with drawing power. The last illustration was apt in which God's transforming love is clearly manifested. Thus the application was powerful. It seems, however, that exegesis and interpretation of the main text are lacking. The core of the message did not come from the preaching passage, but from 1 John 4:8-11. One can be confused about whether the preaching passage is Jas $1: 15-18$ or 1 John $4: 8-11$. It is a topical sermon.

Summarizing the Analysis

1. The sermon is not controlled by a single unified text. 
2. The exegesis and contextual study of the preaching passage are lacking.

3. The explanation is persuasive.

4. The sermon is Christ-centered.

5. The sermon is well illustrated.

6. The sermon is well applied.

7. It is not an expository sermon.

\section{Sermon Number 10}

\section{Background}

This sermon was preached for the workers of Seoul Adventist Hospital during a spiritual emphasis week.

\section{Synopsis}

The sermon title was "The Condition of Happiness." The preaching passage: 1 John 4:9-10.

Unless plants respond to sunlight, they may experience nourishment growth, but they may not experience reproductive growth. Likewise, unless we respond to God's love, we may live metabolic growth, but we may not live reproductive growth.

God gave us mothers so that we may understand and experience God's love. My two children are in the states. So every evening we feel empty. We miss them. One day my son in California was playing basketball and his feet were injured. He had to have a serious operation. My wife flew to him to take care of him. He said to her, "Mom, it is 
strange. When I was apart from you, I ate too much. But now I eat only a little." Mother's love is an expression of God's love. When a wayward child sees mother's love, he begins to be mature. Likewise, when we understand God's love, we grow toward maturity. When we respond to God's love manifested through the cross, we have life.

Until the mid-nineteenth century at the hospitals in Europe, medical students and doctors examined pregnant women without washing their hands after they had done an autopsy. Thus the death rate of women was high. Then a man realized where the problem was. He made a regulation that all the medical students and doctors must wash their hands after they had done an autopsy. As a result, while in April 1847 fifty-seven women died, in June that year, of forty-two women examined, only one died. After a month, it was only one of eighty-four women that died. But germs were known to spread also from patient to patient. The man made another regulation that all the medical students and doctors must wash their hands whenever they diagnosed and treated patients. Many doctors protested. Eventually this man's contribution was forgotten, and he died alone in the psychiatric ward. But 3,500 years ago God said, "Whoever touches the dead body of anyone will be unclean for seven days. He must purify himself with the water on the third day and on the seventh day; then he will be clean" (Num $19: 11,12)$. If people had practiced the laws of cleansing 
since then, numberless people would have been saved from death. The Bible is a guidebook for life science.

Chun Won Gwang Soo Lee, a famous literary man, wrote of a woman named Sun Ok, an Adventist. He wrote about the Adventists' pure and noble lifestyle, expressing his favorable impression and love toward her. It has happened when individuals or institutions faithfully obeyed God's law that they reflected to the world God's glory. When the word of God is obeyed, the world will better know God. And the world will respond to His love.

It seems that you are wondering why the Battle Creek Adventist Hospital failed. The hospital did not lack patients. It worked well. Because the hospital prospered, Dr. Kellogg decided to follow his own way instead of God's principles. He entered into pantheism and left the Church. Before the hospital fell, the man fell. In spite of the world-famous hospital and college, Ellen white saw the man's fall and suggested that the Church should leave Battle Creek. As a result, the school moved to Berrien Springs, Michigan, and the hospital moved to Loma Linda, California. The hospital in Battle Creek suddenly burned down. Although it was rebuilt, because of heavy debt it was handed over to the government. Dr. Kellogg's house, which was the home of fifty orphans, was eaten by a swarm of ants. So it was burned down. I pray you can see from the Word and history 
that humbly obeying the Word of God is the way to happiness and prosperity.

In the hydrotherapy room at weimar the students assist the patients as volunteers. The first thing for them to do is to pray for the patients. Then the patients begin to weep in heart. They begin to think of the days when they hated others or treated their spouses cruelly. They begin to repent. There are those who have never grasped their wives' hands in their lifetime. They weep at the unselfish love of the students. While they take a walk they begin to grasp their wives' hands and their diseases begin to be healed. Love is the life-giving power. When love is responded to, disease begins to be healed.

St. Helena is in the mountains. Mrs. Ellen white suggested there should be a sanitarium and hospital there. There are no big cities around st. Helena Adventist Hospital. There is a korean medical doctor named Dr. Oh. A cardiosurgeon, he has so many personal patients that if he goes on vacation the other assistants should go on vacation. He memorizes the names of his patients, and remembers the situations of their family members. He is so interested in his patients' lives and happiness that his patients like him and bring other patients. So he contributes to the hospital's being full of patients.

Last winter I had the opportunity to visit são Paulo in Brazil. With Mexico City and Shanghai, this city is one 
of the three largest metropolitan cities in the world. As the number of other hospitals increased, the Adventist hospital in Sâo Paulo faced difficulties in management. Then the hospital established a sanitarium at a quiet place. The sanitarium has doctors and nurses. Because diseases of adult people last a long time, rich patients are coming. The sanitarium profited for the first time in the recent history of the Adventist hospital. The ideal health institution which God revealed to Mrs. Ellen white was a sanitarium and hospital. This suggests that man should cooperate with God. That is, modern medicine should be harmonized with natural remedies. We will see that when modern medicine is in God's hand, wonderful healing power will be manifested. God will show a way for the Adventist hospital that is following $\mathrm{Him}$. God saves us not because we grasp God but because He loves us. It is not true that God loves us because we are worthy. Rather, God regards us as worthy because He loves us. I pray that you will personally experience God's love and salvation, and that you will be God's faithful coworkers.

\section{Analysis}

The preaching passage is 1 John 4:9-10. The message is: We should respond to God's love and obey His principles as coworkers of God. Of the seven illustrations, five are those about medical workers and institutions, which are appropriate for the workers of Seoul Adventist Hospital. 
The illustration of cleansing hands strongly shows why God and the Bible are the guide of life science. The illustration of Dr. Kellogg powerfully shows the end of those who do not obey God. And the illustrations of Weimar students and Dr. Oh of St. Helena Hospital show how workers should work. The last illustration shows which direction the hospital should go. Therefore the illustrations had clear purposes for the message.

The message was Christ-centered, and the application was appropriate. However, the illustration of a mother's love did not fit the whole message, though it was used as an expression of God's love. The exegesis and contextual study of the preaching passage were lacking. The title of the sermon is "The Condition of Happiness." The message did not come from the exposition of the preaching passage. The preaching passage speaks of God's love. But the message is about responding to God's love and obeying His principles. It is a topical sermon, not expository.

\section{Summarizing the Analysis}

1. The message is not controlled by the preaching passage.

2. The exegesis and contextual study of the preachig passage were lacking.

3. The explanation is persuasive.

4. The message is Christ-centered.

5. The sermon is well illustrated. 
6. The sermon is well applied.

7. It is not an expository sermon.

\section{Sermon Number 11}

\section{Background}

The preacher is in his fifties. He has worked as a pastor for more than twenty years. He is now working in one of the largest churches in the East Central Korean

Conference. This sermon was preached on the Sabbath that was the last day of the year-end prayer week.

\section{Synopsis}

The sermon title was "The Gift of Forgiveness." The preaching passage was Ps $130: 1-8$.

The Israelites ascertained God's forgiveness through the judgment of the Urim and Thummim on the plate made of twelve jewels on the high priest's breast. Then they were invited to enjoy the Feast of Tabernacles. Likewise, on this last day of year-end prayer week, we have received God's forgiveness!

Sin is the most fundamental problem which human beings should solve. Man can't solve it for himself. God solves it! God is the God of forgiving. The word "forgive-ness" is for giving. Forgiveness is the most wonderful gift of God to humankind. It is the gospel! A person who is forgiven has joy. What are the purposes for which God forgives? 
First, God forgives us so that we may stand before Him. "If you, O LORD, kept a record of sins, O Lord, who could stand?" (Ps $130: 3$ ). It is not the most important thing to receive the office of elder or deacon. It is not the most important to be rich. To be able to stand before God is the most important thing in life. The Apostle John in Revelation heard the cry of many people and wrote: "For the great day of their wrath has come, and who can stand?" (Rev $6: 17$ ). I pray that you will receive God's forgiveness so that you may stand before God.

Second, God forgives us so that we may fear God. "But with you there is forgiveness; therefore you are feared" (Ps 130:4). The Psalmist said, "Out of the depths I cry to you, O LORD" (PS 130:1). Adventists seem to have little zeal for prayer. One day I finished preaching during prayer emphasis week at Gwang Chun Adventist Academy. An eleventh-grade girl student came to me. She was the daughter of a pastor of a Holiness Church. She said, "If your Church is the true Church, why don't Adventists have zeal for prayer?" Pray fervently and deeply so that you may have the assurance of forgiveness. Those who are forgiven can forgive others. Only those who can forgive others can love them.

Third, God forgives us so that He may redeem us from all our sins. "He himself will redeem Israel from all their sins" (Ps 130:8). The word "redemption" includes atonement 
and salvation. Jesus paid the price for our sins by giving His life to forgive our sins and save us from sin. Therefore let's receive God's gift of forgiveness. The Psalmist said, "My soul waits for the Lord more than watchmen wait for the morning, more than watchmen wait for the morning" (Ps 130:6). I graduated from Korean Union College, working as a watchman. The most difficult time for me as a watchman was before dawn. Then I felt coldest, most hungry and sleepy. When morning came, I could warm myself up, eat food, rest, and see my loved one. Therefore a watchman eagerly waits for the morning. Let's wait for the Lord, more than watchmen wait for the morning. Let's receive God's forgiveness and wait for the glorious morning of our Lord's second coming. Today your sins are forgiven!

\section{Analysis}

The exposition of the text with three divisions filled the sermon. The preacher turned the congregation to the joy of forgiveness and waiting for the second coming of the Lord. By proclaiming "your sins are forgiven," the congregation must be filled with freedom, joy, hope, and the excitement of a new beginning!

Few illustrations, however, were adopted except two little ones of a girl student and his watchman experience. Also the second division lacked unity. That is, though he said, "God forgives us so that we may fear God," he emphasized the need of praying deeply. An explanation was 
needed on what relationship existed between fearing God and praying deeply. The explanation of the relationship between forgiveness and the zeal for prayer was lacking. In addition, the third division, "God forgives us so that He may redeem us from our sins," is not clear. An explanation of the relationship between forgiveness and redemption was lacking. Though the preacher said over and over again, "You should receive God's forgiveness," it is not certain that this sermon is Christ-centered. Furthermore, systematic exegesis and contextual study of the preaching passage and its explanation were lacking. It is a topical sermon.

\section{Summarizing the Analysis}

1. The sermon was not controlled by the preaching passage.

2. The sermon was not analyzed with adequate exegesis.

3. The explanation is not clear.

4. The sermon is Christ-centered.

5. Illustrations are lacking.

6. The sermon is applied to people's needs.

7. It is not an expository sermon.

Sermon Number 12

\section{Synopsis}

The sermon title was "Let's Obey God's Commandments." The preaching passage was Ps 119:125-129. 
The Seventh-day Adventist Church is the Church of those who "obey God's commandments and remain faithful to Jesus" (Rev 14:12). God's remnant is those who "obey God's commandments and hold to the testimony of Jesus" (Rev 12:17). This world is morally corrupted. In our country, from politicians to the common people, many become corrupt. In Ps 119:125 the word "discernment" means not just intellectual knowledge but experiential knowledge. Ps 119:126 says, "Your law is broken." Even some church members think that they don't have to faithfully keep the Sabbath holy because God is love. Now is the time for God to act (Psalm 119:126). Satan is performing many wonders and miracles in the churches. The ecumenical movement is maturing. The world is rushing toward religious war. This is Armageddon. In this end time God entrusted His law to us. Therefore we should love God's commands more than pure gold (Ps 119:127). The Psalmist says, "Because I consider all your precepts right, I hate every wrong path" (Ps 119:128). Today people are confused between right and wrong. Holding to the testimony of Jesus does not necessarily mean having the writings of Ellen G. White. It does mean obeying God's commandments ( 2 Cor $6: 1-10$ ). Let us obey God's commandments.

\section{Analysis}

The preacher tried to explain that God's people should obey God's commandments. However, neither the text 
itself nor the context are explored to discover the beauty and depth of God's law. 2 Cor $6: 1-10$ is a part of the theme "the ministry of reconciliation," which the Apostle Paul expounded. Therefore 2 Cor 6:1-10 was not in harmony with this sermon's theme.

The sermon was not Christ-centered. The grace of Christ is the power which can have His people obey God's commandments with voluntary love. The harmony of grace and law was not explained. Christ was not lifted up. The sermon does not confront the congregation with its real need of obeying God's commandments. Little illustration was given. Application was not sufficient. It is a topical sermon.

\section{Summarizing the Analysis}

1. The message has a preaching passage; however, it was not controlled by it.

2. The proposed text was not exegetically analyzed.

3. The explanation is clear.

4. It is not a Christ-centered sermon.

5. The sermon is not well illustrated.

6. Application was not sufficient. 
Sermon Number 13

\section{Background}

The preacher is working as pastor of a church in a city in the vicinity of seoul. He is now in his early forties and graduated from Sahmyook University.

\section{Synopsis}

The sermon title was "Daniel's Faith" The preaching passage was Dan 1:3-8.

Daniel was regarded as righteous along with Job, by his contemporary prophet Ezekiel (Ezek 14:14). He was highly esteemed by God (Dan 9:23). His life shone like the brightness of the heavens. All this resulted from his resolve to do God's will.

The king of Babylon attempted to "babylonize" Daniel and his three friends, as Japan made Koreans speak only Japanese and had their names changed into Japanese names. The king of Babylon used education as a tool of "babylonizing" Daniel and his three friends. An official "was to teach them the language and literature of the Babylonians" (Dan 1:4).

Babylon had a well-developed civilization. The country created the lunar calendar and initiated the twelvemonth year. It made one day twenty-four hours, and one hour sixty minutes. It was Babylon that made the disposition of sixty. Babylonians also studied astronomy and described constellations, naming them with the names of animals and so 
forth. In addition, they invented the signs of the zodiac. These were transferred through Mesopotamia, Egypt, and China to Korea and Japan. It was then that the dispositions of sixty and two were made. The disposition of two is one of the basics of the computer. The culture and education of Babylon were for worshiping idols, and those of the Hebrews were for worshiping God. The ultimate purpose of education is to restore the image of God in people. The essential elements of education should be (1) nature, which represents the nature of God, (2) experience, which is the counterpart of theoretical education, (3) work, which stimulates people's physical, mental, and spiritual powers, and (4) the Scriptures, which testify to Jesus Christ. NEWS (nature, experience, work, and Scripture) should be the important factors of education.

Babylon attempted to change Daniel and his three friends through foods. People's frames and muscles are made from what they eat. Their minds and characters are shaped by what they eat. Our first ancestors lost Paradise by uncontrolled appetite. Mrs. Ellen White wrote:

With Christ, as with the holy pair in Eden, appetite was the ground of the first great temptation. Just where the ruin began, the work of our redemption must begin. As by the indulgence of appetite Adam fell, so by the denial of appetite Christ must overcome (The Desire of Ages, 118).

In Aesop's Fables, a king demanded the most delicious food in the world. A tongue was brought in. To the surprised king, an explanation was given: "Tongue sings 
beautiful songs, and impresses people's minds and hearts." Then the king demanded the worst food in the world. A tongue was brought in. To the even more surprised king, an explanation was given: "Tongue slanders and eats bad foods." The control of the tongue is one of the issues of the great controversy.

Meat has not been the best food. It was allowed after the Deluge. The average span of life from Adam to Noah was 912 years. But that from Shem to Abraham was 317 years. Now it is not easy for people to live one hundred years. Meat has shortened the span of life. It has also degraded people's minds and characters. If Daniel and his three friends had submitted themselves to the king's assigned foods, we would not have had Dan 2 and the rest of the book.

Daniel and his three friends didn't eat the king's assigned foods (Dan 1:5). Rather, they ate the appointed foods of the King of kings (Gen 1:29). Those who eat the appointed foods of the King of kings and obey His will by faith will eat the fruit of life in the kingdom of heaven. Babylon changed the names of Daniel and his three friends into Babylonian names. Like Babylon, this age is full of idol worship and wrong education and indulgence. In this sinful age let's set our will Godward. 
Analysis

The text is explored with historical and contextual exegesis and explanations were undertaken with good

illustrations. Although the essential elements of education such as nature, experience, work, and scripture are explained, what God has done for us and what the congregation should do were not clear.

In the sermon Christ was not presented as the one who enables each Christian to obey God's will. It may be difficult to call this sermon Christ-centered or Godcentered. The problems of the hearers were described in an abstract way. Therefore, the application was not clear. It is not an expository sermon.

Summarizing the Analysis

1. The sermon was controlled by the leading text.

2. The text was explored with historical and contextual exegesis.

3. The explanation was clear.

4. The sermon was not Christ-centered.

5. The sermon was well illustrated.

6. The application was not clear.

7. It is not an expository sermon. 


\section{Synopsis}

The sermon title was "The True sea Route of Life." The preaching passage was Ps 107:1-32.

It is assumed that this psalm was written in 530 B.C. after the Israelites had returned from Babylonian captivity.

They had to pass through the Arabian Desert. I had an experience of passing through a desert. The scorching heat was terrible. Some of the Israelites lost direction and wandered in desert wastelands, finding no way to a city where they could settle. Some of them ate their last bread. After that they were hungry. Some of them drank the last water. After that they were thirsty. Their lives ebbed away .

The woman at the well of Sychar, Samaria, met Jesus, who is the Water of Life. To her Jesus was an Oasis. Likewise when they cried out to the Lord in their trouble, God delivered them from their distress. He led them by a straight way to a city where they could settle.

We all are pilgrims passing through the desert of this world. We didn't know the way to the City of Jerusalem in heaven. And we were thirsty without the water of Life, Jesus. But Jesus came to us, and gave us the water of Life. He also showed us the way to the heavenly holy city. Praise the Lord! 
The Scriptures say, "Some sat in darkness and the deepest gloom, prisoners suffering in iron chains, for they had rebelled against the words of God and despised the counsel of the Most High" (Ps 107:10-11). This is talking about captivity. We can see that in the passages, "broke away their chains" (vs. 14), "he breaks down gates of bronze and cuts through bars of iron" (vs. 16). God saved them from captivity.

The psalmist said, "They loathed all food and drew near the gates of death" (vs. 18). This means serious illness. But God "saved them from their distress. He sent forth his word and healed them" (vs. 19). Let's obey the health principles. God said:

If you listen carefully to the voice of the LORD your God and do what is right in his eyes, if you pay attention to his commands and keep all his decrees, I will not bring on you any of the diseases I brought on the Egyptians, for I am the LORD, who heals you (Exod 15:26).

This promise is conditional. If you keep God's commandments, God will heal you.

Verses 23 through 30 describe traveling by boat. In those days a boat was one of the most common means of transportation for a long journey. But now the airplane is.

When I worked in military service, I worked with Captain Choi. One day because of his excellence in doing duty at the special operation training for a month, Lieutenant General Hong Hwan Kim presented a prize to him and he was promoted to major. I had the privilege of being 
with Lieutenant General Kim. But when I was discharged from military service, Major Choi died of liver and stomach cancer. After this I happened to hear on the radio in my home that Lieutenant General Kim met his death in a helicopter accident. I doubted this, but it was proved that the pilot had made a fatal error. This world is full of accidents. So is the spiritual world. This world is full of spiritual danger. So let's set a correct air route. And let's obey Jesus, the control tower commander.

\section{Analysis}

The preacher spoke of God who saved His people (1) from wandering in the desert, hungry and thirsty, leading them to a city where they could settle, (2) from captivity, deepest gloom, and death, (3) from serious illness, and (4) from tempest and waves. Historical and contextual exegesis and explanation were undertaken.

The preacher made an illustration of the woman at the well in Sychar, Samaria, and Jesus. Jesus was described as the water of Life and the Oasis in the desert. But in the text Christ was described as the guide of His people. Thus the water of life and guide are not in accordance. The preacher could have made an illustration of Jesus as the Guide.

At the illustration of the fourth division, the preacher said that the reason why Lieutenant General Kim met his death in a helicopter accident was because the pilot of 
the helicopter had got drunk. But the preacher pleaded with the congregation to set a right air route. These things are not parallel to each other.

To emphasize that this world is full of accidents, the preacher spent too much time. Emphasizing this is not the main point.

The preacher said, "Let's obey the health message," "Let's obey Jesus, the control tower commander." He emphasized obeying, but Jesus was not presented as the one who enables His people to obey. Jesus, His grace, and gospel were not fully represented.

For application, the preacher said, "Let's set a correct air route." If he had said, "Let's accept this Lord and have a right relationship with Him now, " the application would have been sharp instead of being too general and blunt.

The sermon was lacking in adequate exegesis. It is not an expository sermon.

\section{Summarizing the Analysis}

1. The sermon seems to be controlled by the preaching passage.

2. The text was not analyzed with adequate exegesis.

3. The explanation was not clear and persuasive.

4. The sermon was not Christ-centered.

5. The illustrations were lacking. 
6. Application was not clear.

7. It is not an expository sermon.

\section{Observations/Conclusions}

In chapters 2 and 3 the theology of preaching and the definitions of expository preaching were explored to sharply define and better understand expository preaching so that the criteria for expository preaching could be obtained. Using these criteria along with established principles of interpretation and homiletical rules, the above fourteen taped sermons were analyzed in this chapter.

\section{Observations}

From the study the following observations can be made:

1. How to exegete a chosen biblical text needs to be better understood and practiced by the Korean pastors. Sermons $1,2,4,5,6,7,9,10,11,12$, and 14 lack this important process-79 percent of the fourteen sermons.

2. Some sermons tried to explain what the preacher wanted to say, instead of what the chosen passage meant. Sermons $1,4,5,7,11$, and 14 are in this category.

3. Christ was not exalted in some sermons. The Bible testifies to Jesus, the Savior of the world. Therefore this element must be one of the most important for expository preaching. In sermons $4,12,13$, and 14 it is lacking. 
4. In some sermons, the application is vague or superficial. For example, in sermon 14, the preacher said, "Let's set a correct air route in life." In sermons 1, 12, 13, and 14 that vagueness is detected.

5. Illustrations should fit the explanation. In sermons 4, 11, and 12 good illustrations are lacking. And in sermons $I$ and 14 , better illustrations are needed. See table 1 .

TABLE 1

CLASSIFICATION AND EVALUATION OF FOURTEEN SERMONS

\begin{tabular}{|c|c|c|c|c|c|c|c|c|c|c|c|c|c|c|}
\hline & \multicolumn{14}{|c|}{ Preachers } \\
\hline \multirow[t]{2}{*}{ Criteria } & \multicolumn{2}{|c|}{ A } & \multicolumn{2}{|c|}{ B } & \multicolumn{2}{|c|}{ C } & \multicolumn{2}{|c|}{ D } & \multicolumn{2}{|c|}{$E$} & \multicolumn{2}{|c|}{$\mathrm{F}$} & \multicolumn{2}{|c|}{ G } \\
\hline & 1 & 2 & 3 & 4 & 5 & 6 & 7 & 8 & 9 & 10 & 11 & 12 & 13 & 14 \\
\hline Leading text & & & * & & & & & * & & & & & * & * \\
\hline Exegesis & & & * & & & & & * & & & & & * & \\
\hline $\begin{array}{l}\text { Explanation \&c } \\
\text { persuasion }\end{array}$ & & $*$ & * & & & $*$ & & $*$ & * & * & & $*$ & $*$ & \\
\hline $\begin{array}{l}\text { Christ- } \\
\text { centered } \\
\text { message }\end{array}$ & * & * & * & & * & * & * & $*$ & * & * & $*$ & & & \\
\hline Illustration & & * & * & & * & $*$ & * & * & * & * & & & * & \\
\hline Application & & $\star$ & $\rightarrow$ & $*$ & * & * & * & * & * & * & & & & \\
\hline
\end{tabular}

Note: * represents presence of a specific criterion; A-G represents the preachers; $1-14$ represents the sermons.

Thus, it turns out that the solid understanding of how to make an expository sermon is greatly needed. Therefore a course outline for expository sermon preparation 
is presented in the Appendix. It is made up of six sessions: Establishing the Text, Exegesis, Interpretation, Christ-Centered Preaching, Application, and Preacher's RSVP. Obviously this course outline is not an exhaustive one. It will need improvement in the years to come, but it is the first step toward effective teaching of expository preaching in the Korean Adventist context.

\section{Conclusions}

From these studies the following conclusions may be drawn :

1. Of fourteen sermons analyzed, topical sermons are eleven ( 86 percent), textual sermon is one ( 7 percent), and expository sermons are only two (14 percent).

2. There is a strong need to educate Korean pastors about how to make expository sermons. In this highinformation society, the standard of regularly educating the people in the pews is getting higher and higher. The congregation needs, wants to hear, and cries out for Scripture-based, quality biblical sermons. Expository preaching can fill that need. Therefore, it is essential to teach pastors how to do an exegetical analysis of the text so that compelling expository preaching can be done. 3. The Christ-centered gospel should be the theme of each message. In Adventist pulpits in Korea an eschatological message and a "we should be better" theme has prevailed. As Ellen White said, with the lack of sermons on 
Christ and Him crucified the churches are as dry as the Mount of Gilboa. Christ and the cross should be lifted up. This cannot be overly emphasized because the third angel's message is that of righteousness through faith in Jesus Christ.

4. Finally, it is imperative that pastors and lay leaders receive adequate training in a continuing education program for expository preaching. Furthermore, the theology students of Sahmyook University, the future Adventist preachers of Korea, should learn how to research and construct a good expository sermon.

As far as I know, this analysis and evaluation of fourteen recorded sermons represents the first formal investigation of the preaching content and structure of Adventist pastors in Korea using the criteria of expository preaching. Therefore, it will facilitate the future study of this method, and it is hoped, stimulate the development of preaching skilis in Korea.

Bad preaching is hard to listen to and effective, good preaching is rare. It is my prayer that through fresh, intelligent, relevant, and spirit-filled expository preaching, the pulpit and the pew in Korea will experience an increased and ongoing revival in Jesus Christ, and that this gospel will be preached to all people as soon as possible so that we all may soon meet the Lord Jesus Christ in the air. 
APPENDIX

A MODEL OUTLINE FOR A COURSE IN EXPOSITORY PREACHING 
Lesson One: ESTABIISHING A TEXT

\section{Purpose of the study}

To select the appropriate text for the sermon.

\section{Study outine}

I. Advantages of Having a Text

A. For the preacher

1. It will help the preacher focus on the text.

2. It provides the sermon with contents and message.

3. It will help the preacher preach a Christcentered message. The scriptures testify to Christ (John 5:39).

B. For the congregation

1. The text gives the congregation the opportunity to think about it.

2. The text can give the congregation insight and illumination.

3. The text can help the congregation remember the theme of the sermon.

II. Factors in Establishing a Text

A. General rules

1. Choose a text considering the spiritual needs of the congregation.

2. Choose a text that is not too difficult to deal with.

3. Choose a lucid and clear text.

4. Choose a text which has sufficient spiritual foods.

B. Some considerations

1. Do not choose an obscure text as far as possible. 
2. Do not fear the familiar text.

3. When historical texts are chosen, the story must be fully told.

III. The Text and the Sermon
A. The main thought of the text should be the main thought of the sermon.
B. Do not be satisfied with broad generalities.
C. All the crucial points of the text should form the main points of the sermon.
D. Important issues of the text should not be omitted from the sermon.

IV. Some Considerations on Establishing the Text
A. When a preacher reads the Bible, he should not read it to hunt some texts for a sermon. Let the texts hunt you.
B. "Every preacher, with the clearly recognized right, would have to accept the duty of being a thinker in the things of God" (Phillips Brooks, 124).
C. Establish the text as soon as possible and dwell on it in prayer.
The preaching of a real sermon is no mere human transaction. It is a divine and human partnership. 
Lesson Two: EXEGESIS

\section{Purpose of the study}

To learn about the original intention of the writer of any selected text.

\section{Study outline}

I. The Importance of Exegesis

A. Exegesis is the "historical investigation into the meaning of the text" (Gordon D. Fee, New Testament Exegesis, 21).

B. Sincere exegesis helps the preacher prepare a basis for a fresh, informative, intelligent, and rich sermon.

C. Faithful exegesis enables the preacher to make a relevant interpretation of the text and thus a persuasive and powerful sermon.

II. Some Common Pitfalls of Exegesis

A. Transference. This respects the cultural and historical gap and difference between what the text "meant" and what it "means."

B. Allegorization. This ignores the historical context.

C. Parallelism. This assumes the same situation today.

D. Disregarding the connection of the text. This is due to:

1. A sentence taken away from its context.

2. Excessive use of short texts.

3. Carelessly-made divisions that sadly disregard the connection and obscure the sense.

E. Moralizing. This simplifies the mystery of the gospel and produces sin lists or bumper-sticker theology.

III. Exegesis of the Text

A. Begin with prayer. 
"Diligent prayer is more than half the study" (Martin Luther).

B. Try to get the content. What did it say?

C. Read the text in its context. Why did the author say this? What do the passages around the chosen passage say? For example, the Apostle Paul wrote 1 Cor 2:9 not to describe the beauty of the Paradise but to describe the depth of the wisdom of the saving God.

D. Read also the remote context. How is the text in harmony with the whole biblical context? For instance, Luke 16:19-31 was not said by Jesus to teach the conditions of the dead but to teach that in front of the Pharisees and people is the one testified to by Moses and the prophets (verse 31)-Jesus, the central theme of the scriptures.

E. Ascertain whether the language of the text is literal or figurative-e.g., Luke 16:19-31.

F. Read the text in different English and Korean translations and see any significant differences. E.g.:

1. Matt 5:44: "Pray for those who persecute you" (NIV). "Pray for them which despitefully use you, and persecute you" (KJV).

2. Gen 3:17: "Cursed is the ground because of you" (NIV). "Cursed is the ground for thy sake" (KJV).

G. Know the circumstances pertaining to the writer and the addressee.

1. Understand the individuality of the writer, the style, and mode of expression-e.g., the writers of the four Gospels.

2. Know under what circumstances the text was written-e.g., 1 Cor 12-14.

3. Understand the character of the people to whom the words were addressed-e.g., Galatians.

4. Learn:

a. When did the writer write the passage?-e.g., Phil 4:4-7. 
b. Who are involved in this matter?-e.g., John $8: 1-11$.

c. What were geographical, economical, social, political, and spiritual situations at the time the passage was written?-Luke 10:25-37.

H. Limit the chosen pericope. Make sure that the passage chosen is a genuine self-contained unit.

I. Study theologically important words-e.g., "the word" in the context of Greek culture, "Iight," and "grace."

J. Study the grammatical and lexical data, and the genre of the passage.

1. Lexical data-e.g., "agapao" and "phileo" (John $21: 15-18$ ).

2. Grammatical data. What are the tenses, moods, and number?-e.g., John 5:24. Is the person talking in first, second, or third person?-Gen $3: 15$.

3. The genre: Is it prose, poetry, a saying, or a hymn?

4. Be on the alert for the words, "therefore," "moreover," "but," "nevertheless," etc.

K. Compare Scripture with Scripture-e.g.:

Matt 14:18, "Sit down on the grass."

Luke 9:15, "And everybody sat down."

Mark 6:39, "Then Jesus directed them to have all

the people sit down in groups on the green grass."

This may make the preacher think of the Apostle Peter's vivid recall of his Master's power and the writer's exciting wonder.

L. Investigate other resources about your text after you take the steps mentioned so far, such as Bible commentaries, Bible dictionaries, Bible encyclopedias, and books of sermons.

M. The Results of Good Exegesis

1. Good exegesis of a text is not a sermon, but it provides the preacher a great amount of 
information to share with the congregation. Exegesis can be a store to feed the sermon. It is a gateway for interpretation and application.

IV. The Flow of Sermon Construction

BIBLICAL TEXT

(What it says)

$$
\downarrow
$$

INTERPRETATION OF TEXT

(What it meant)

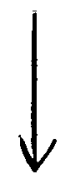

THE CONTEMPORARY SITUATION

(What it means) 
Lesson Three: EXPLANATION

\section{Purpose of the study}

To know how to interpret what the text says.

\section{Study outline}

I. The Importance of Biblical Interpretation

A. Much of the weakness and ineffectiveness of sermons is due to incorrect, insufficient, and improper interpretation of the text.

B. Good interpretation will enable you to apply the meaning of the text to the congregation's present needs.

II. Principles of Interpretation

A. All preaching must be biblical preaching. It should have a text to be analyzed with the natural divisions of the text, and the theological implication of the text.

B. The Scriptures have unity. For example, there is no basic disagreement between the theology of Paul and the theology of James. The same Holy spirit guided all the Bible writers. Therefore, despite their individual difference, a fundamental oneness persists.

C. Let Scripture explain Scripture.

1. The preacher must be willing to scuttle a "brilliant" preaching idea if he discovers it to be out of harmony with the real meaning of the text in the context of parallel or explanatory passages.

2. Study parallel texts of the old Testament with the New Testament.

3. Study parallel texts of the Synoptic Gospels.

D. Proper interpretation of biblical words and sentences is essential. For instance, the word "faith" may mean "saving faith" in the highest Christian sense; it may mean "assenting to an idea"; it may refer to faithfulness. As many as six different meanings of faith have been detected in Paul's epistle to the Romans. 
E. The context and historical background are to be explored. The preacher must be aware of the author, the circumstances of writing, the time and place of writing, and the reason for writing. This information may not be made obvious in the sermon, but it needs to be part of the preacher's equipment as he prepares his sermon. Horrible blunders have been made by preachers who neglected the contextual and historical background of the text on which they worked.

F. The message of the Bible is to be interpreted literally unless it is obviously figurative.

G. The correct use is to be made of the typological principle.

III. Some Considerations on Interpretation

A. Decide at what level you engage the text. E.g.:

Phil 2:5-11 Christology or example

Matt 10:34-36 on one level it confronts compromise and apathy.

At another level it encourages those already paying the price.

B. Ask yourself at what level you identify with the text.

1. Listen to the Word-linguistic questions

2. Listen to the listeners-historical, contemporary questions

3. Listen to self-discipleship questions

C. Struggle with interpretation.

1. As an exegete the preacher struggles with the Word of God.

2. As a man of God the preacher struggles with what the Word is doing in him to transform him.

3. As a preacher he struggles with what God is saying to the congregation through him. 
Lesson Four: CHRIST-CENTERED PREACHING

\section{Purpose of the study}

To demonstrate that Christ is to be the central theme in all biblical preaching.

\section{Study outline}

I. The Reasons Why All Biblical Preaching should Be Christ-Centered.

A. The Scriptures testify to Jesus Christ (John $5: 39)$.

The doctrine of the Scriptures is Jesus Christ and Him crucified ( 1 Cor $2: 1-5$ ).

B. Preaching means preaching Christ.

"Let the science of salvation be the burden of every sermon, the theme of every song. . . . Bring nothing into your preaching to supplement Christ" (Gospel Workers, 160).

C. Only preaching Christ will draw people and transform them (John 12:32).

"One interest will prevail, one subject will swallow up every other-Christ our Righteousness" (R.H. Extra, Dec. 23, 1890).

D. Preaching Christ will finish the gospel work.

"The world will not be converted by the gift of tongues, or by the working of miracles, but by preaching Christ crucified" (Testimonies to Ministers, 424).

E. Preaching Christ is proclaiming the third angel's message of Rev 14.

"Where the people assemble to worship God let not a word be spoken that shall divert the mind from the great central interest-Jesus Christ, and Him crucified. The third angel's message is to be our burden of warning. The side issues are not for us to meddle with" (Testimonies to Ministers, 331).

F. The only saving preaching is preaching christ (Acts $4: 12$ ). 
"Our churches are dying for the want of teaching on the subject of righteousness by faith in

Christ" (Gospel Workers, 301).

II. The Example of the Apostles

A. How did Paul preach?

1. Paul spoke of the duties of husbands in relation to their wives; but in doing so he preached Christ (Eph 5:25-33).

2. Paul laid down the principles of church discipline; but in doing so he preached Christ (1 Cor $5: 1-7$ ).

B. How did Peter preach?

1. He was setting forth the duties of servants to their masters; but in doing so he preached Christ (1 Pet $2: 18-25$ ).

III. The Central Factor of Biblical Preaching

A. "The fire and wood are here,' Isaac said, 'but where is the lamb. . .?'" (Gen 22:7).

The zeal and enthusiasm of the fire of the , preacher is needed. Also the intelligence of the wood of the preacher is indispensable. But the Lamb is the central factor of all biblical preaching. Every preacher should find in his thicket the Lamb whom God prepared (Mervyn Warren). 
Purpose of the study

To know how to apply what the text says to the congregation's present needs.

\section{Study outline}

I. The Importance of Application

A. In application God speaks to the contemporary congregation.

B. In application the people's present needs are fulfilled.

C. In application transformation is made.

"After studying the lives of hundreds of preachers and reading countless sermons, we concluded that the preachers who made the greatest impact upon the world were men who spoke to the issue and needs of their days" (Clyde E. Fant, 5).

II. Irrelevant Sermons

A. Irrelevant sermons are:

1. Those ending with moralistic exhortations or pietistic yearning rather than the gospel.

2. Those that go round and round inside the text but never come to focus in the lives of the hearers.

3. Those that are not focused on the person of Jesus Christ.

III. Applying the Message to the Needs of People

A. Make sure what the purpose of the sermon is:

1. Consider the main points that you need to proclaim.

2. Decide what your audience needs to know from the text.

3. Decide what transformation your audience should experience through your sermon. 
B. For good application be a good exegete not only of your text but also of your congregation.

C. Basic presuppositions about your congregation for good application (John Rapp's lecture handout).

1. People are God's masterpiece but they have forgotten what the Bible has to offer them.

2. People want to be taken seriously: Preach above, never below them.

3. People need a home to join.

4. People want old Bible truth in a fresh way. They want the presence of God's truth on Sabbath morning, not others' opinions.

5. People want the gospel affirmed. They want the Gospel not defended but testified to.

6. People want certainty in this age of pluralism.

7. People want room to disagree and to be part of the process in coming to biblical truth; debate and dialogue are necessary.

8. People are not looking for entertainment but to be fed consistently.

9. People do not expect the gospel to be easy. Birth and transformation are always painful.

10. People are not expecting quick fixes. Transformation takes time.

11. People do not like dogmatic moralism nor urbane liberalism.

12. People want the preacher to say what needs to be said and sit down. The more the preacher says the less people remember. 
Lesson Six: PREACHER'S RSVP

\section{Purpose of the Study}

preaching.

To learn about the conditions of effective

\section{Study outline}

I. Rsvp—Read

A. One who does not read well does not preach well. People are saturated with media ads and entertainments.

B. To fulfill Isa 58:11, "The LORD will guide you continually, and satisfy your soul in drought, and strengthen your bones; you shall be like a watered garden, and like a spring of water, whose waters do not fail" (NKJV). Good reading helps preaching like a well-watered garden.

C. Some resources for reading

1. Newspaper-The world loves a story, because it is inductive.

2. Reader's Digest-this represents conservative mindset of people.

3. Theology

4. Commentaries

5. Biographies

6. Psychology, history, science

7. Journals (Christianity Today, Leadership, etc.)

8. Adventist Review

9. The writings of Ellen $\mathrm{G}$. White

10. The Bible

D. Don Jacobson's idea-"Wherever you sit down, read."

E. Reading will help your preaching be fresh. 
F. Fresh preaching comes from a reading preacher.

II. rSvp-study

A. Moving much will broaden you, but not deepen you . Studying deepens you.

B. Top priority: uninterrupted time

1. Make your congregation aware that you study and will not always be available during study time, except for emergencies.

2. Establish a routine of time and place.

3. Study regularly.

4. Resist the temptation to stop studying when the sermon is done.

5. Set up your own working library.

6. Preserve the fruit of study for another day, sermon, series.

7. Be adamant about the importance of study-it is an act of pastoral care and a huge part of your job description.

8. Study is necessary to make preaching as fruitful for the preacher as it should be.

C. Studying will help make your preaching intelligent.

D. Intelligent preaching comes from a studying preacher.

"Learn to study for the sake of truth, learn to think for the profit and the joy of thinking. Then your sermons shall be like the leaping of a fountain and not like the pumping of a pump" (Phillips Brooks, 160).

III. rsVp-Visit

A. Be a lover of people.

B. The new management style is MBWA (Management By Wandering About). 
C. Do not be satisfied with knowing people's problems, situations, and needs at a surface level. Know them at an in-depth level.

D. Visiting will help make your preaching relevant.

E. Relevant preaching comes from a visiting preacher.

IV. rsvP-Pray

A. Power in the pulpit comes from praying in the closet.

B. Billy Graham: "If I could begin again, I would study more and pray more."

C. Praying will help your preaching be spirit-filled.

D. Spirit-filled preaching comes from a praying preacher.

(Much of the contents of Lesson Six: Preacher's RSVP, is owed to Dwight Nelson's handout and his special lecture titled "The Joyful Tyranny: How to Live Behind the Pulpit and Under the Gun." The lecture was given at Andrews University on June 18, 1996, for the Lake Union Conference pastors' meeting.) 


\section{SELECTED BIBLIOGRAPHY}

Achtemeier, P. T. An Introduction to Hermeneutics. Philadelphia, PA: Westminster, 1969.

Adams, Jay E. Essays on Biblical Preaching. Grand Rapids, MI : Zondervan, 1983.

Araujo, Ramon C. "A Biblical Preaching strategy for the Ministers of the Seventh-day Adventist Central Dominican Conference." D.Min. project report, Andrews University, 1987.

Bailey, Raymond. Paul the Preacher. Nashville, TN: Broadman, 1991 .

Blackwood, Andrew $W$. Expository Preaching for Today: Case Studies of Bible Passages. Nashville, TN : Abingdon-Cokesbury, 1953. - Preaching from the Bible. Nashville, TN: Abingdon-Cokesbury, 1941. - The Fine Art of Preaching. New York: Macmillan, 1952 . - The Preparation of Sermons. New York: Abingdon-Cokesbury, 1948.

Broadus, John A. A Treatise on the Preparation and Delivery of Sermons, 7th ed. New York: A. C. Armstrong and Sons, 1899 .

Brooks, Phillips. Lectures on Preaching. London: H. R. Allenson, 1871.

Brown, Charles R. The Art of Preaching. New York: Macmillan, 1934 .

Brown, H. C. Jr. A Quest for Reformation in Preaching. Waco, TX: Word, 1968.

Brunner, Emil. Revelation and Reason. Philadelphia, PA: Westminster, 1946. 
Bryson, Harold T. Expository Preaching: The Art of Preaching Through a Book of the Bible. Nashville, TN : Broadman \& Holman, 1995.

Buswell, Robert Evans, Jr. "Buddhism in Korea." The Encyclopedia of Religion. 1987. 2:421.

Carver, W. O. Out of His Treasures. Nashville, TN: Broadman, 1956 .

Clowney, Edmund. Preaching and Biblical Theology. Grand Rapids, MI: Eerdmans, 1961.

Colquhoun, Frank. Christ's Ambassadors. Philadelphia, PA: Westminster, 1965.

Dabney, Robert L. Sacred Rhetoric: Or a Course of Lectures 1979 . on Preaching. Carlisle, PA: Banner of Truth,

Dodd, C. H. Apostolic Preaching and Its Developments. New York: Harper \& Brothers, 1949.

Ebeling, Gerhard. Word and Faith. Translated by James W. Leitch. London: SCM Press, 1963.

Encyclopedia of Religion and Ethics. Edited by James Hastings. New York: Charles Scribner's Sons, 1921. S.v. "Shamanism."

Evans, C. F. Is Holy Scripture Christian? London: SCM Press, 1971.

Fant, Clyde E. Preaching for Today. Rev. ed. New York: Harper \& Row, 1975.

Farmer, Herbert $H$. The Secret of the Word. New York: Charles Scribner's Sons, 1942.

Fee, Gordon D. New Testament Exegesis. Philadelphia, PA: Westminster, 1983.

Ford, D. W. Cleverley. The Ministry of the Word. Grand Rapids, MI: Eerdmans, 1979.

Forsyth, P. T. Positive Preaching and Modern Mind. London: Hodder and Stoughton, 1907.

Gill, S. D. "Shamanism." The Perennial Dictionary of World Religions. Edited by Keith Crim. New York: Harper \& Row, 1989. 674 . 
Grieve, Alexander James. "Preaching." The Encyclopedia Britannica. 13th ed., 1926. 22:263.

Haselden, Kyle. The Urgency of Preaching. New York: Harper $\&$ Row, 1963 .

Holland, Dewitte T. The Preaching Tradition. Nashville, TN: Abingdon, 1980 .

Hoppin, James M. Homiletics. New York: Funk \& Wagnalls, 1883 .

Howington, Nolan. "Expository Preaching," Review and Expositor 56 (January 1959): 58 .

Jones, Bob, Jr. How to Improve Your Preaching. New York: Fleming $\mathrm{H}$. Revell, 1945.

Kamphaus, Frank. The Gospel for Preachers and Teachers. London: Sheed and Ward, 1974.

Keck, Leander. The Bible in the Pulpit. Nashville, TN: Abingdon, 1978 .

Kerr, Hugh Thompson. Preaching in the Early Church. New York: Fleming H. Revell, 1942.

Knott, Harold E. How to Prepare an Expository Sermon. Cincinnati, OH: Standard Publishing, 1930.

Koller, Charles W. Expository Preaching without Notes. Grand Rapids, MI: Baker, 1962.

Leith, John H. "Calvin's Doctrine of the Proclamation of the Word and Its Significance for Today in the Light of Recent Research." Review and Expositor 86 (Winter 1989): 32,34 .

Lloyd-Jones, Martyn. Preaching and Preachers. Grand Rapids, MI: Zondervan, 1972.

MacArhur, John, Jr., and the Master's Seminary Faculty. Rediscovering Expository Preaching. Dallas, TX: Word, 1992.

Macleod, Donald. The Problem of Preaching. Philadelphia, PA: Fortress, 1987.

Mann, C. S. The Message Delivered. New York: Morehouse Barlow, 1973 . 
Meyer, F. B. Expository Preaching Plans and Methods. New York: George H. Doran, 1910.

Miller, Donald G. Fire in Thy Mouth. Nashville, TN: Abingdon, 1954 .

Montgomery, R. Ames. Expository Preaching. Westwood, NJ: Fleming $H$. Revell, 1939.

Mounce, Robert $H$. The Essential Nature of New Testament Preaching. Grand Rapids, MI: Eerdmans, 1960.

Nelson, Dwight. "The Joyful Tyranny: How to Live Behind the Pulpit and Under the Gun." Lecture handout for the Lake Union Conference pastors' meeting. Berrien Springs, MI: Andrews University, 1996.

Pease, Norval F. "Hermeneutical Principles Applied to Preaching." In A Symposium on Biblical

Hermeneutics, ed. Gordon M. Hyde. 257-261.

Washington, DC: Review and Herald, 1974.

Phelps, Austin. The Theory of Preaching. New York: Charles Scribner's Sons, 1894 .

Ramm, Bernard. Hermeneutics. Grand Rapids, MI: Baker, 1971.

- Protestant Biblical Interpretation. 3rd ed. Grand Rapids, MI: Baker, 1970.

Rapp, John B. "Expository Preaching." Lecture handout for the Lake Union Conference pastors' meeting. Berrien Springs, MI: Andrews University, 1996.

Ray, Jefferson D. Expository Preaching. Grand Rapids, MI: Zondervan, 1940 .

Reed, David. Preparing to Preach. New York: George H. Doran, 1911.

Richardson, Neil. Preaching from Scripture. London: Epworth Press, 1983.

Robinson, Haddon W. Biblical Preaching. Grand Rapids, MI: Baker, 1980 .

Stott, John R. W. Between Two Worlds: The Art of Preaching in the Twentieth Century. Grand Rapids, MI:

Eerdmans, 1982 . 
"Biblical Preaching Is Expository Preaching." In Evangelical Roots: A Tribute to Wilbur Smith, ed. Kenneth S. Kantzer. 161. Nashville, TN: Thomas Nelson, 1979.

Taylor, William M. The Ministry of the Word. New York: Anson D. F. Randolph, 1876.

The Europa World Year Book (London: Europa Publications, 1993), 2:1693.

The World's Great Sermons. Compiled by Grenville Kleiser. 10 vols. New York: Funk \& Wagnalls, 1908.

Thiselton, Anthony C. The Two Horizons. Grand Rapids, MI: Eerdmans, 1980 .

Thompson, William D. A Listener's Guide to Preaching. Nashville, TN: Abingdon, 1966.

- Preaching Biblically: Exegesis and Interpretation. Nashville, TN: Abingdon, 1981.

Unger, Merrill F. Principles of Expository Preaching. Grand Rapids, MI: Zondervan, 1955.

Vincent, Marvin R. The Expositor in the Pulpit. New York: Anson D. F. Randolph, 1884.

Warren, Mervyn. "Where Is the Lamb?" Lecture in memory of H. M. S. Richards, Sr. Berrien Springs, MI: Andrews University, 1996.

White, Douglas M. The Excellence of Exposition. Neptune, NJ: Loizeaux Brothers, 1977.

- He Expounded. Chicago: Moody, 1952.

White, Ellen G. The Desire of Ages. Mountain View, CA: Pacific Press, 1964.

- Gospel Workers. Washington, DC: Review and Herald, 1915.

- Medical Ministry. Mountain View, CA: Pacific Press, 1963.

- The Ministry of Healing. Mountain View, CA: Pacific Press, 1942. - Testimonies for the Church. 9 vols. Mountain View, CA: Pacific Press, 1948. 
- Testimonies to Ministers and Gospel Workers. Mountain View, CA: Pacific Press, 1962.

Whitesell, Faris D. The Art of Biblical Preaching. Grand Rapids, MI: Zondervan, 1950.

Fleming H. Revell, 1967.

Wiersbe, Warren W., and Lloyd M. Perry. The Wycliffe Handbook of Preaching and Preachers. Chicago: Moody, 1984 .

Wingren, Gustaf. The Living Word. Philadelphia, PA: Muhlenberg Press, 1960.

Zuck, Roy B. Basic Bible Interpretation. Wheaton, IL: Victor Books, 1991. 
VITA

Date of Birth: March 6, 1957

Wife: Namsoo (Park)

Child: Justin Chunglo

\section{Education}

1979: Bachelor of Business Administration

Yonsei University, Seoul, Korea

1983: Master of Business Administration

Yonsei University, Seoul, Korea

1986: Master of Arts in Religion

Sahmyook University, Seoul, Korea

1993: Master of Divinity

Andrews University

1996: Doctor of Ministry

Andrews University

\section{Professional Experience}

1981-1984: Full-Time Instructor of Business Administration Sahmyook University

1984-1991: Pastor

West Central Korean Conference in Korea

1990 : Ordained Pastor of Korean Union Conference

1995-1996: A Member of the Board of Directors of the Korean Adventist Press for the Korean Seventh-day Adventists in North America

1995-1996: A Member of the Advisory Committee of the Michigan Conference of Seventh-day Adventists 